\title{
RAY OF LIGHT? \\ DIETRICH VON FREIBERG UND DIE GESCHICHTE VON DER MITTELALTERLICHEN WISSENSCHAFT ${ }^{1}$
}

\author{
Daniel Cohnitz
}

\begin{abstract}
In dieser Untersuchung werden drei wissenschaftshistorische Theorien bezüglich des Übergangs von mittelalterlicher zu moderner Wissenschaft idealtypisch unterschieden: die Katastrophentheorie, die Theorie völliger Kontinuität und die Theorie einseitiger Kontinuität. Orientiert an der Entwicklungsgeschichte der Optik, insbesondere an der Geschichte der Erklärung des Regenbogens von Aristoteles bis Descartes wird dafür argumentiert, daß die Theorie einseitiger Kontinuität die wohl zutreffendste wissenschaftshistorische Auffassung darstellt. Das bedeutet einerseits, daß wir in den Bereichen mittelalterlicher Naturerkenntnis, die man am ehesten als „Wissenschaften“ bezeichnen kann, hin zur Moderne eine eher kontinuierliche Methodenentwicklung feststellen können (die Katastrophentheorie also falsch ist): Bereits Dietrich von Freiberg verfügt auf methodischer Seite über dieselben Verfahren und Mittel, die Descartes das Rätsel des Regenbogens schließlich lösen lassen. Andererseits bedeutet dies aber, daß der Übergang zur Moderne durch einen bedeutenden Bruch auf theoretischer Ebene charakterisiert ist (was gegen die Theorie völliger Kontinuität spricht).
\end{abstract}

\section{Einleitung}

\section{Dear Sir,}

The development of Western Science has been based on two great achievements, the invention of the formal logical system (in Euclidean geometry) by the Greek philosophers, and the discovery of the possibility of finding out causal relationships by systematic experiment (Renaissance). In my opinion one needs not be astonished that the Chinese sages have not made these steps. The astonishing thing is that these discoveries were made at all.

Sincerely yours, A. Einstein ${ }^{2}$

So lautet die mittlerweile berühmt gewordene Erklärung Einsteins für das Problem der einzigartigen Entstehung des kulturellen Projektes moderne Wissenschaft im Westen Europas. Diese drei Sätze des berühmtesten Physikers unseres Jahrhunderts enthalten bereits die Kernfragen der Wissenschaftsgeschichte und zugleich deren populärste Antworten.

Zunächst die Auffassung, daß das, was moderne Wissenschaft ausmacht oder hervorbrachte, in der Entstehung wissenschaftlicher Methoden zu suchen ist (die Entwicklung der formalen Logik mit der Euklidischen Geometrie sowie die Möglichkeit Kausalbeziehungen mit kontrollierten Experimenten zu ermitteln). Es ist insbesondere

\footnotetext{
${ }^{1}$ Besonders herzlich möchte ich meinem Lehrer Professor Dr. Rudolf Hiestand danken, der diese Arbeit betreute und wertvolle Verbesserungsvorschläge zu früheren Versionen dieses Textes machte. Ebenfalls danken möchte ich Dr. Hans-Alois Weber und Prof. Dr. Christoph Kann für weitere kritische Hinweise und Marcus Rossberg für die technische Unterstützung bei der Erstellung der Reproduktionen. Frühere Versionen von Teilen dieses Textes sind an den Universitäten Tartu und Düsseldorf vorgetragen worden. Von den fruchtbaren Diskussionen habe ich vieles lernen können. Ich hoffe, mir ist es gelungen zumindest einiges davon in dieser Arbeit wiederzugeben.

${ }^{2}$ Zitiert nach: Alistair C. Crombie: The Relevance of the Middle Ages to the Scientific Movement. Aus: Alistair C. Crombie (Hrsg.): Science, Optics and Music in Medieval and Early Modern Thought. London (Hambledon Press) 1990, S. 41.
} 
diese Frage, die die Forschung des Wissenschaftshistorikers mit der Analyse des Wissenschaftstheoretikers verbindet.

$\mathrm{Ob}$ man die Bedeutung von kontrollierten Experimenten für den wissenschaftlichen Fortschritt untersucht oder Qualitätsmerkmale wissenschaftlicher Theorien (wie z. B. Einfachheit) analysiert, man wird diese Probleme heute nicht mehr ohne das Material der Wissenschaftshistoriker beantworten wollen. Auf der anderen Seite kann der Historiker sich bei der Untersuchung, Darstellung und Interpretation historischer Forschung der ausdifferenzierten Systeme der analytischen Philosophen bedienen. Allerdings muß man einschränkend anmerken, daß bei der Frage nach dem Verhältnis zwischen Methoden- und Theorienwandel (wie wir noch sehen werden) philosophische Zurückhaltung erfolgversprechender ist. ${ }^{3}$

Als nächstes beinhaltet Einsteins Stellungnahme die verbreitete Vorstellung, daß die Wurzeln der modernen Wissenschaft in der Antike liegen und sie erst durch die Renaissance den zweiten Impuls erhielt, der sie zu einer der erfolgreichsten kulturellen Errungenschaften des westlichen Europas machte. Eine Vorstellung, die implizit das Bild des dunklen dogmatischen und wissenschaftlich unfruchtbaren Mittelalters transportiert ${ }^{4}$, einer Zeit, in der ein Disput über philosophische Prinzipien mehr Welterkenntnis versprach als Beobachtung und Experiment, in der verstaubten, dicken lateinischen Büchern so viel Autorität zukam, daß ihre Verteidigung ständig mit dem Preis empirischer Adäquatheit bezahlt wurde.

Diese Auffassung spiegelt sich auch in aktuellen Darstellungen zur Geburt der Wissenschaft wider. „La naissance de la science“ von André Pichot ${ }^{5}$ thematisiert ausschließlich die frühe Antike, und „La Nascita Della Scienza Moderna in Europa“ von Paolo Rossi ${ }^{6}$ legt den Schwerpunkt deutlich auf die Entwicklungen in der Renaissance.

Der dritte Bestandteil der Einsteinschen Erklärung ist dann die Verwunderung darüber, daß diese Entwicklungen überhaupt stattfanden, ein Erklärungsproblem, daß in gewisser Weise erst durch die diskontinuierliche Interpretation der Wissenschaftsgeschichte entsteht. Hier liegt eine zentrale quaestio disputata der Wissenschaftshistoriker: Die Frage nach der Rolle des Mittelalters für die moderne Naturwissenschaft.

Zugleich ist es eine Frage nach der Beurteilung der mittelalterlichen Leistungen. Ist die Erklärung des Regenbogens durch Dietrich von Freiberg und die experimentellen

\footnotetext{
${ }^{3}$ Vgl. zu diesem Thema: Thomas S. Kuhn: Die Beziehung zwischen Wissenschaftsgeschichte und Wissenschaftstheorie. Aus: Thomas S. Kuhn (Hrsg.): Die Entstehung des Neuen: Studien zur Struktur der Wissenschaftsgeschichte. Frankfurt am Main (Suhrkamp) 1992, S. 49-71. Auch wenn ich die Gefahr der philosophischen Voreingenommenheit ähnlich wie Kuhn einschätze, scheint mir dieser Vorwurf als Instrument der Kritik oft etwas zu einfach zu sein. Dazu zählt für mich beispielsweise Fichants Vorwurf gegen Duhem und Rossis Bemerkung, „das unablässige Flechten am Kontinuitätsstrang“ sei „nichts weiter als eine mediokre Geschichtsphilosophie, die der realen Geschichte übergestülpt wird.“ Vgl.: Michel Fichant: Die Idee einer Wissenschaftsgeschichte. Aus: Michel Fichant, Michel Pêcheux (Hrsg.): Überlegungen zur Wissenschaftsgeschichte. Frankfurt am Main (Suhrkamp) 1977, S. 68 und Paolo Rossi: Die Geburt der modernen Wissenschaft in Europa. München (Beck) 1997. (= Europa bauen), S. 21.

${ }^{4} \mathrm{Zu}$ Fragen, die den Zusammenhang von Geschichte und Wissenschaftsgeschichte betreffen, vgl.: Thomas S. Kuhn: Die Wissenschaftsgeschichte. Aus Kuhn: Die Entstehung des Neuen, S. 169-193; Thomas S. Kuhn: Die Beziehung zwischen Geschichte und Wissenschaftsgeschichte. Aus Kuhn: Die Entstehung des Neuen, S. 194-236 und Alistair C. Crombie: What is the History of Science. Aus: Crombie: Science, Optics, S. 441-451.

${ }^{5}$ André Pichot: Die Geburt der Wissenschaft: Von den Babyloniern zu den frühen Griechen. Darmstadt (WBG) 1995. Die französische Erstausgabe erschien 1991.

${ }^{6}$ Paolo Rossi: Die Geburt der modernen Wissenschaft in Europa. München (Beck) 1997.
} 
Untersuchungen, die ihn dorthin führten, ein einsamer Lichtstrahl in einem ansonsten dunklen Zeitalter oder Ergebnis einer kontinuierlichen Entwicklung, einer wissenschaftlichen Tradition? Wie profitierte Dietrich, der in dieser Untersuchung als ein Beispielfall erfolgreichen mittelalterlichen Forschens betrachtet werden soll, von seinen Vorgängern, und wie profitierte die Wissenschaft im weiteren Verlauf ihrer Geschichte von ihm? Um Fragen dieser Art zu klären, muß zunächst ein gewisser theoretischer Rahmen umrissen werden, innerhalb dessen das Mittelalter und seine wissenschaftlichen Leistungen analysiert werden können.

\subsection{Talking 'bout a Revolution: drei Theorien über die Entwicklungsgeschichte der modernen Wissenschaft}

In der wissenschaftshistorischen Forschung, die sich mit der Beziehung zwischen Mittelalter und Moderne sowie mit der Beziehung zwischen Methoden- und Theorienwandel auseinandersetzt, kann man idealtypisch drei verschiedene theoretische Ansätze ${ }^{7}$ identifizieren: ${ }^{8}$

\section{A) Die Katastrophentheorie}

Die Katastrophentheorie, bzw. die Theorie völliger Diskontinuität besagt, daß im Übergang von mittelalterlicher zu neuzeitlicher (moderner) Naturwissenschaft ein starker Bruch innerhalb der Methoden wissenschaftlicher Forschungspraxis stattfand, der einen qualitativen Theorienwandel nach sich zog. Innerhalb dieser Theorie wird „Wissenschaftliche Revolution“ in einem sehr starken Sinne verstanden. Einer der Hauptvertreter dieser Auffassung ist sicherlich Paolo Rossi, dessen Hauptthesen im folgenden noch analysiert werden sollen. ${ }^{9}$

\footnotetext{
${ }^{7}$ Fast jeder dieser Ansätze arbeitet dabei mit dem Begriff der „Wissenschaftlichen Revolution“, ohne daß dieser Terminus in jedem Fall das gleiche Gewicht besitzt. Allen Ansätzen ist aber gemeinsam, daß der Begriff der „Wissenschaftlichen Revolution“ als Zeitraum das 17. Jahrhundert bezeichnet, in dem die Physik innerhalb einer relativ kurzen Spanne eine starke Zunahme in der Theoriendynamik erfuhr.

${ }^{8}$ Es ist vermutlich etwas kühn, solche Typologien aufgrund einiger Kerncharakteristika vorzunehmen, aber es scheint für die von mir verfolgten Zwecke im Grunde unproblematisch zu sein. Für weitere allgemeinere Merkmale der Wissenschaftsgeschichte vgl.: Ulrich Charpa: Philosophische Wissenschaftshistorie. Grundsatzfragen / Verlaufsmodelle. Göttingen (Vieweg) 1995 (=Wissenschaftstheorie, Wissenschaft und Philosophie. 42)

${ }^{9}$ In einer wesentlich schwächeren Variante kann man aber auch Edward Grant zu den Vertretern dieser Theorie zählen. Grant vertritt zwar viele Elemente der Kontinuitätstheorien, greift aber zur Erklärung des starken theoretischen Wandels zur Zeit der Wissenschaftlichen Revolution auf qualitativen Methodenwandel zurück.

Für Grant ist der Hauptunterschied zwischen einem mittelalterlichen Forscher und einem Wissenschaftler wie Kopernikus in der unterschiedlichen Einstellung zum Wahrheitsanspruch wissenschaftlicher Theorien zu sehen. Während der mittelalterliche Wissenschaftler (insbesondere durch die Entwicklung des Nominalismus' im 14. Jahrhundert) seine Theorien über die Welt hypothetisch und ohne realistischen Anspruch formuliere, ändere sich genau dies bei Kopernikus schlagartig, der nicht nur auf eine Bewahrung der Phänomene abzielt, sondern die Welt beschreiben will, wie sie wirklich ist. Diese veränderte Einstellung der Wissenschaftler zu ihren Produkten habe (neben anderen Faktoren) die Wissenschaftliche Revolution ausgelöst. Diese Erklärung Grants erscheint sehr ad hoc und paßt kaum in die Gesamtargumentation des Buches. Vgl.: Edward Grant: Das physikalische Weltbild des Mittelalters. München (Artemis) 1980.
} 


\section{B) Die Theorie völliger Kontinuität}

Ohne zu leugnen, daß innerhalb der Entwicklung der Wissenschaft Zeiträume unterschiedlicher Dynamik in Theorien- und Methodenwandel erkennbar sind, geht die Theorie völliger Kontinuität von ausschließlich quantitativen Änderungen auf beiden Ebenen aus. Aufgrund der allmählichen Ausdifferenzierung der wissenschaftlichen Methode sei es zur kontinuierlichen Zunahme unseres theoretischen Wissens über die Welt gekommen. Alistair C. Crombie ${ }^{10}$ und Pierre Duhem ${ }^{11}$ sind die wohl prominentesten Vertreter dieser Auffassung. Die Theorie völliger Kontinuität teilt mit der Katastrophentheorie die Auffassung, daß Fortschritte in den wissenschaftlichen Methoden (mögen sich diese nun kontinuierlich entwickeln, oder diskontinuierlich entstehen) einen signifikanten Einfluß auf die Entstehung wissenschaftlicher Theorien haben.

\section{C) Die Theorie einseitiger Kontinuität}

Diese These, die man Alexandre Koyré ${ }^{12}$ und in gewisser Hinsicht Thomas S. Kuhn ${ }^{13}$ zuschreiben kann, trennt zwischen Methoden- und Theorienentwicklung. Während sich wissenschaftliche Methoden durchaus kontinuierlich (oder nahezu kontinuierlich) weiterentwickelt haben, zunehmend ausdifferenziert und verfeinert wurden, könne man dennoch von einer Wissenschaftlichen Revolution im Sinne einer theoretischen Revolution sprechen.

Betrachten will ich zunächst die Katastrophentheorie in der Version Paolo Rossis. Es wird sich aber herausstellen, daß die Analyse der Katastrophentheorie auch zur Bewertung der beiden Alternativen geeignet ist. Rossi formuliert fünf Hauptthesen, die für eine ,starke Diskontinuität zwischen der Tradition mittelalterlicher Gelehrsamkeit und der modernen Wissenschaft ${ }^{\text {‘14 }}$ sprechen:

1. Der Naturbegriff der Moderne unterscheidet sich radikal von dem der mittelalterlichen Philosophen, indem er, anders als die Tradition, natürliche und künstliche Körper nicht länger als ihrem Wesen nach verschiedene Entitäten auffaßt.

2. Die Natur wird in der Moderne unter künstlich geschaffenen Bedingungen untersucht. Die Erfahrungen, auf die sich die Aristoteliker berufen, um ihre

\footnotetext{
${ }^{10}$ Vgl.: Crombie Alistair C.: Von Augustinus bis Galilei. Die Emanzipation der Naturwissenschaft. München (dtv) 1977; ders.: Robert Grosseteste and the Origins of Experimental Science 1100-1700. Oxford (Clarendon Press) 1971; ders.: The Relevance, S. 41-71; ders.: The Significance af Medieval Discussions of Scientific Method for the Scientific Revolution. Aus: Crombie: Science, Optics, S. 139160 .

${ }^{11}$ Vgl.: Pierre Duhem: To Save the Phenomena: An Essay on the Idea of Physical Theory from Plato to Galileo. Chicago, London (University of Chicago Press) 1969.

${ }^{12}$ Vgl.: Alexandre Koyre: Die Ursprünge der modernen Wissenschaft: Ein neuer Deutungsversuch. In: Diogenes, 4. Jg. (1957), S. 421-448 und ders.: Von der geschlossenen Welt zum unendlichen Universum. Frankfurt am Main (Suhrkamp) 1980.

${ }^{13}$ Vgl.: Thomas S. Kuhn: Die Struktur wissenschaftlicher Revolutionen. Frankfurt am Main (Suhrkamp) 1996; ders.: Die Grundlegende Spannung: Tradition und Neuerung in der wissenschaftlichen Forschung. Aus: Kuhn: Entstehung des Neuen, S. 308-326; ders.: Die historische Struktur wissenschaftlicher Entdeckungen. Aus: Kuhn: Entstehung des Neuen, S. 239-253 und ders.: Mathematische versus experimentelle Traditionen in der Entwicklung der physikalischen Wissenschaften. Aus: Kuhn: Entstehung des Neuen, S. 84-124.

${ }^{14}$ Rossi: Die Geburt, S. 19.
} 
Theorien zu beweisen oder zu veranschaulichen, gehen von der alltäglichen Lebenswelt aus. Die „Erfahrungen“ der modernen Forscher beruhen auf künstlichen Experimenten, die eigens zu dem Zweck durchgeführt werden, Hypothesen zu bestätigen oder zu widerlegen.

3. Die moderne Wissenschaft ähnelt der Erforschung eines neuen Kontinents, die mittelalterliche der beharrlichen Auslotung von Problemen nach kodifizierten Regeln.

4. Der neuzeitlichen Kritik begegnen die Scholastiker nicht mit einer Untersuchung der Natur, sondern mit einer Untersuchung ihres Wissens über die Natur, die immer zu befriedigenden Antworten führt. In diesem Wissen ist nur Platz für Lehrer und Schüler, nicht aber für Erfinder.

5. Die modernen Wissenschaftler - allen voran Galilei - gehen mit einer „Unbefangenheit" und einem „methodologischen Opportunismus“ zu Werke, die der mittelalterlichen Tradition gänzlich unbekannt sind. Der mittelalterliche Anspruch absoluter Genauigkeit hat die Entwicklung einer mathematischen Naturwissenschaft eher behindert als gefördert. [... $]^{15}$

Die erste und zweite These Rossis scheinen mir in einer gewissen logischen Beziehungen zueinander zu stehen, und zwar dergestalt, daß das Zutreffen der Beschreibung, die in der ersten These gegeben wird, eine hinreichende Bedingung für das $\mathrm{Zu}$ treffen der zweiten These zu sein scheint. Wenn die aristotelische Trennung zwischen natürlichen und künstlichen Entitäten im Mittelalter immer noch eine Denkschranke für die Wissenschaftler darstellte, dann machten kontrollierte künstliche Experimente keinen Sinn, wollte man mit ihnen etwas über die Natur erfahren. Unter der Annahme, daß sich auch mittelalterliche Wissenschaftler rational verhielten, würde der Nachweis, daß sie tatsächlich künstliche Experimente durchführten (in der Absicht damit etwas über die Natur zu erfahren), gegen die zweite und damit auch gegen die erste These sprechen. Dieser Frage will ich im Hauptteil der Untersuchung anhand mittelalterlicher Beispielfälle nachgehen.

Die dritte und die fünfte These beschreiben den modernen Wissenschaftler (im Gegensatz zum mittelalterlichen) als einen unkonventionellen, methodisch innovativen Forscher, der kritisch und unbefangen die jeweils zeitgenössische Theorie durchleuchtet. $\mathrm{Ob}$ dieses Bild des modernen Forschers eine zutreffende Beschreibung darstellt, wird im nächsten Abschnitt erörtert. Ob im Gegensatz dazu der mittelalterliche Forscher prinzipiell autoritätshörig und methodisch konservativ war und unter dem „lähmende[n] Mythos absoluter Genauigkeit“ litt, werde ich wiederum im Hauptteil behandeln. ${ }^{16}$

Die vierte These scheint sich besonders auf das Verhalten der Scholastiker in der Phase der wissenschaftlichen Revolution zu beziehen. Wenn dieses Verhalten traditionelle mittelalterliche Praxis darstellt, wäre dieser Befund erklärt, wenn nicht, wäre er in Frage zu stellen: ein Problem, das ebenfalls mit den Beispielfällen beleuchtet werden soll, aber im nächsten Abschnitt auch aus der Perspektive der modernen Wissenschaft betrachtet wird.

\footnotetext{
${ }^{15}$ Rossi: Die Geburt, S. 19-20.

${ }^{16}$ Auch die Fragen der Mathematisierung und zunehmenden Quantifizierung innerhalb der Naturwissenschaft werden dort erörtert.
} 


\subsection{Die Katastrophentheorie und die moderne Wissenschaft}

,[D]aß es in der Wissenschaft oft besser sei, mit den vorhandenen Mitteln das Beste herauszuholen, als sich andersartige Ansätze zu überlegen “'17, wäre nach Rossis Auffassung die Maxime des mittelalterlichen Forschers. Es ist aber gerade die Maxime der modernen, der reifen Wissenschaft. Der moderne Naturwissenschaftler forscht nach Regeln, die mehr oder weniger kodifiziert von den Paradigmata ${ }^{18}$ der Wissenschaften vorgegeben sind:

Kaum irgendwelche Forschung auch der größten Wissenschaftler geschehen in revolutionärer Absicht, und nur sehr wenige haben irgendeine revolutionäre Wirkung. Im Gegenteil, die normale Forschung, auch die beste, ist etwas höchst Konvergentes und stützt sich nachdrücklich auf eine stabile Übereinstimmung der Auffassungen, die mit der wissenschaftlichen Ausbildung erworben und in dem nachfolgenden Berufsleben verstärkt worden ist. ${ }^{19}$

Ich halte dies für ein wichtiges Merkmal, das die moderne Naturwissenschaft mit zunehmender Reife ausbildete, ein Merkmal, das beispielsweise die mittelalterliche Optik, wie ich noch zeigen werde, gar nicht besaß.

Gerade die Lehrtradition, die „dogmatische Einführung in eine vorgegebene Tradition, die der Student nicht bewerten kann “20, kennzeichnet nach Thomas Kuhn die besondere Form der Ausbildung in den modernen Naturwissenschaften. Im überwiegenden Teil hat demnach auch die moderne Naturwissenschaft nur Platz für Lehrer und Schüler, und es ist unter anderem dieser Aspekt, der sie zu eben diesem effektiven Kulturprodukt macht, das wir kennen.

Ähnliches gilt meiner Auffassung nach für Rossis Diagnose eines modernen Opportunismus und eines mittelalterlichen Präzisionswahns bezüglich quantitativer Untersuchungen. Die ,romantische Suche nach der nächsten Stelle hinter dem Komma“'21, die den modernen Erforscher fundamentaler Konstanten mit Leidenschaft erfüllen kann, besitzt unter einer funktionalistischen Sichtweise sicherlich ihre Berechtigung $^{22}$, sie läßt sich aber wohl kaum mit Begriffen wie „Unbefangenheit“ oder „methodologischer Opportunismus“ beschreiben.

\footnotetext{
${ }^{17}$ Kuhn: Die grundlegende Spannung, S. 308.

${ }^{18}$ Zur näheren Erläuterung des Begriffs Paradigma im obigen Sinne vgl.: Thomas S. Kuhn: Neue Überlegungen zum Begriff des Paradigma. Aus: Kuhn: Entstehung des Neuen, S. 389-420 und Kuhn: Die Struktur.

${ }^{19}$ Kuhn: Die grundlegende Spannung, S. 310.

${ }^{20}$ Kuhn: Die grundlegende Spannung, S. 313.

${ }^{21}$ Ian Hacking: Einführung in die Philosophie der Naturwissenschaften. Stuttgart (Reclam) 1996, S. 405.

${ }^{22} \mathrm{Zu}$ Thomas Kuhns funktionalistischer Interpretation dieser Praktik vgl. Hacking: Einführung, S. 403404: „Einige Soziologen [...] pflegten so vorzugehen, daß sie innerhalb einer Gesellschaft oder einer Subkultur eine bestimmte Praktik ausfindig machten und dann nicht in Frage stellten, wie sie dorthin gelangt sei, sondern warum sie sich gehalten habe. Sie vermuteten, daß diese Praktik unter Voraussetzung anderer Eigenschaften der betreffenden Gruppe Vorteile aufweist, die zur Erhaltung der Gesellschaft selbst beitragen. Dies sei die Funktion dieser Praktik. Dabei könne es durchaus sein, daß die Angehörigen dieser Gesellschaft nichts von dieser Funktion ahnen. [...] In ähnlicher Weise gelangt Kuhn zu der Auffassung, daß das Messen in der Physik eine zunehmend wichtige Rolle spielt. [...] Kuhn behauptet, daß die Anomalien, die unter der Herrschaft präziser Messungen unweigerlich zum Vorschein kommen, die anschließende Tätigkeit konzentrieren, so daß es, um in seiner Terminologie zu reden, womöglich sogar zu einer Krise kommt. Außerdem werde durch die Anomalien bestimmt, was es für eine Theorie bedeute, eine frühere Theorie befriedigend zu ersetzen. Das Messen nimmt also eine wichtige Nische ein im Rahmen von Kuhns Auffassung des Ablaufs normale Wissenschaft / Krise / Revolution / neue normale Wissenschaft.“
} 


\subsection{Die Katastrophentheorie und die Wissenschaft des Mittelalters}

Sofern es die Aussagen über die Moderne betrifft, halte ich Rossis Katastrophentheorie aufgrund der obigen Argumente für fragwürdig. Für eine systematische Untersuchung seiner Thesen über die mittelalterliche Wissenschaft sind noch einige methodische Vorbemerkungen nötig, die meine Herangehensweise von der Paolo Rossis abgrenzen.

Ich teile die Auffassung Thomas Kuhns ${ }^{23}$, daß Wissenschaftsgeschichte im Besonderen die Untersuchung wissenschaftlicher Theorien und wissenschaftlicher Praktiken zum Gegenstand hat. Man kann diese mit historisch-sozialen Bedingungen erklären, aber die Geschichte der Wissenschaftsentwicklung ist nicht die Geschichte des „Diskurs darüber, was Wissenschaft ist oder sein soll“'24. Mir scheint eine Vorgehensweise, die sich an „Diskursen“ orientiert, in eine methodische Falle zu tappen, da sie Gefahr läuft, der Rhetorik des 17. Jahrhunderts zu viel Vertrauen entgegenzubringen. Methodologische Programmschriften, die uns sehr „modern“ anmuten, findet man auch vor dem 17. Jahrhundert (zum Beispiel bei Robert Grosseteste oder Roger Bacon), wie „modern“ ihre Forschungen aber tatsächlich waren, erfährt man daraus nicht.

Rossi bemerkt beispielsweise richtig, daß der Forscher des 17. Jahrhunderts für seine Ergebnisse in starkem Maße Anspruch auf Originalität und Neuheit erhebt:

Die Protagonisten der wissenschaftlichen Revolution einte ein weiteres starkes Band - das
Bewußtsein, daß durch ihr Werk etwas Neues entstehe. Der Begriff novus kehrt mit nahezu
obsessiver Häufigkeit in Hunderten von Titeln wissenschaftlicher Bücher des 17. Jahrhunderts
wieder - von der Nova de universis philosophia Francesco Patrizis und der Newe Attractive
Robert Normans über das Novum Organon Bacons bis hin zur Astronomia Nova Kepplers und
den Discorsi intorno a due nuove scienze von Galilei. ${ }^{25}$

Ob dieser Anspruch mehr Aussagekraft besitzt als das Etikett „Neu“ oder „Jetzt mit neuer Formel“" auf einer Shampoowerbung der Gegenwart, wird durch diesen Befund alleine nicht erhellt. Hierzu scheint eine Untersuchung des Gehaltes der Wissenschaft immer noch notwendig.

Für das Mittelalter sind bereits umfangreiche Vorarbeiten für die Geschichte der Optik geleistet worden, derer ich mich bedienen werde, um ein meiner Auffassung nach differenzierteres Bild der mittelalterlichen Wissenschaft $\mathrm{zu}$ zeichnen. Be-

\footnotetext{
${ }^{23}$ Kuhn: Geschichte und Wissenschaftsgeschichte, S. 199-200: „Bedeutsamer ist die merkwürdige Einseitigkeit, mit der die Historiker an die Wissenschaften herangehen, sei es aufgrund primärer oder sekundärer Quellen. Wenn der Historiker z. B. mit der Musik oder den bildenden Künsten zu tun hat, liest er wohl Konzertprogramme und Ausstellungskataloge, aber er hört auch Symphonien und sieht Bilder an, und von ihnen handelt seine Erörterung, auf welche Quellen sie sich auch stütze. Hat er jedoch mit der Wissenschaft zu tun, so liest und diskutiert er fast ausschließlich programmatische Werke [...]“ und S. 204: „In zahlreichen anderen Fällen ergeben sich charakteristische Schwächen aus der oben beschriebenen vorwiegenden Orientierung des Historikers an Vorworten und programmatischen Werken. Werden wissenschaftliche Ideen ohne Bezug auf die konkreten fachlichen Probleme erörtert, um deretwillen sie geschaffen wurden, so führt das zu einer eindeutig irreführenden Vorstellung von der Entwicklung wissenschaftlicher Theorien und ihrer Wirkung auf die außerwissenschaftliche Welt.

Eine Form der systematischen Fehlorientierung wird besonders deutlich in den Diskussionen über die Wissenschaftliche Revolution, auch bei vielen älteren Wissenschaftshistorikern: Man betont übermäßig die Rolle neuer Methoden, vor allem, daß das Experiment von sich aus neue wissenschaftliche Theorien schaffen könne."

${ }^{24}$ Rossi: Die Geburt, S. 21

${ }^{25}$ Rossi: Die Geburt, S. 16.
} 
schränken will ich mich insbesondere auf die Vorgeschichte, die zur Erklärung des Regenbogenphänomens durch Dietrich von Freiberg geführt hat. Diese Vorgeschichte beginnt im 13. Jahrhundert und handelt von Forscherpersönlichkeiten wie Robert Grosseteste, Albertus Magnus, Roger Bacon und Witelo.

\section{Methodologie und Theorie in der Optik des 13. Jahrhunderts}

Im 13. Jahrhundert haben wir zwar, wie ich noch zeigen werde, keine reife Wissenschaft der Optik, in dem Sinne, daß es in der Optik noch kein einheitliches Paradigma $\mathrm{gab}^{26}$, dennoch eignet sich die Optik für diese Untersuchung in besonderem Maße.

Die Optik gehörte wie die Astronomie und die Statik zu den sogenannten ,klassischen Naturwissenschaften“, im Gegensatz zu den „Baconischen Wissenschaften““27, die aus der experimentellen Bewegung des 17. Jahrhunderts überhaupt erst entstanden. Nur hier sind Kontinuitäts- und Traditionsvergleiche zwischen Mittelalter und Moderne möglich. Außerdem ist die Optik eine Wissenschaft, die sowohl auf deduktive Verfahren (Geometrie), wie auf experimentelle Methoden zurückgreift. Sie besaß recht früh einen gewissen Kanon von Problemstellungen, deren Lösungsansätze sich durch die Geschichte verfolgen lassen, und war relativ unbehelligt von theologisch-naturwissenschaftlichen Konflikten.

\section{1 perspectiva und Neoplatonismus}

Das, was wir heute als „Optik“ bezeichnen, formierte sich allmählich im 13. Jahrhundert als Wissenschaft der perspectiva:

This science was concerned with such matters as the nature and propagation of light and color, the eye and the vision, the properties of mirrors and refracting surfaces, image formation by reflection and refraction, and meteorological phenomena involving light. Moreover, it took a broad view of these topics, refusing to confine itself to mathematical description or causal analysis, but insisting on a unified approach that investigated the mathematics, the physics, the physiology, and even (to a limited extend) the psychology and epistemology of the visual process. $^{28}$

Den Anstoß zur zunehmenden Beschäftigung mit der perspectiva bildeten lateinische Übersetzungen griechischer und arabischer Autoren, allen voran zunächst die Übersetzung der ersten Hälfte von Platons Timaeus. Der Text war zwar schon seit dem vierten Jahrhundert auf Latein zugänglich, zog aber erst mit dem zwölften Jahrhundert die Aufmerksamkeit auf sich. Die bis dahin dominierenden Arbeiten des Neoplatonikers Augustinus von Hippo (354-430) wurden übertroffen von neuen Arbeiten auf

\footnotetext{
${ }^{26}$ Vgl. Kuhn: Die grundlegende Spannung, S. 314.

${ }^{27} \mathrm{Zu}$ dieser Trennung vgl.: Kuhn: Mathematische versus experimentelle Tradition. Die Trennung ermöglicht auch eine neue Rolle für Mertons These, da durch sie nun die Entwicklung der Baconschen Wissenschaften erklärt werden kann. Vgl.: Robert K. Merton: Puritanismus und Wissenschaft. Aus: Robert K. Merton (Hrsg.): Entwicklung und Wandel von Forschungsinteressen: Aufsätze zur Wissenschaftssoziologie. Frankfurt am Main (Suhrkamp) 1985, S. 59-85.

${ }^{28}$ David C. Lindberg: The Science of Optics. Aus: David C. Lindberg: Studies in the History of Medieval Optics. London (Variorum Reprints) 1983, S. 338.
} 
der Grundlage des Timaeus, wie denen eines Adelard von Bath und Wilhelm von Conches. $^{29}$

Wirklich grundlegende Neuerungen, die dann zur Kanonbildung führten, wurden aber erst durch die im zwölften Jahrhundert erstmalig im Westen auftauchenden Übersetzungen herbeigeführt. Hierzu gehörten die Optica und Catoptrica von Euclid (Mitte oder zweite Hälfte des 12. Jahrhunderts), die Optica des Ptolemaeus (etwa gleichzeitig), De aspectibus von al-Kindi und De speculis oder De aspectibus von Tideus (zweite Hälfte des 12. Jahrhunderts) und schließlich im frühen 13. Jahrhundert die einflußreiche Übersetzung von Alhazens (Ibn al-Haythams) De aspectibus oder Perspectiva:

These treatises defined the subject matter of optics or perspectiva. The works of Euclid, Ptolemy, Tideus, and al-Kindi were concerned principally with vision and visual radiation, including the propagation of the latter. Alhazan's great tome gave equal prominence to light and also devoted modest attention to the anatomy and physiology of the eye. Light, vision, and the eye: these became the central core of the science optics. The rules of perspective were included under vision. Reflection and refraction were dealt with as accidents of either light or visual radiation, occurring as the result of encounter with an opaque or transparent surface. [...] And meteorological phenomena, such as the rainbow, came to be viewed as important appendages of optics. ${ }^{30}$

Diese neuen Texte transportierten gleichzeitig gewisse methodische Standards (bzw. ganze Methodologien). Euclid's Optica ist erwartungsgemäß weitestgehend reduziert auf die Analyse geometrischer Linien, und Alhazens De aspectibus integriert sowohl physikalische, wie physiologische und geometrische Analysen.

Diese Texte, die für das dreizehnte Jahrhundert zu kanonischen Werken wurden, waren allerdings zu inkohärent untereinander, um ein einheitliches Paradigma der jungen perspectiva zu schaffen. Viele Zusammenhänge blieben zu unklar, viele Aussagen waren zu widersprüchlich, als daß die Wissenschaftler des 12. Jahrhunderts einfach diesen Corpus hätten übernehmen (und damit mit ihren Forschungen daran anknüpfen) können. Es mußte ausgewählt und neu kombiniert werden, und in einigen Fällen wurden auch ganz neue Ansätze entwickelt.

Insbesondere die perspectiva des späten 13. und 14. Jahrhunderts stand außerdem unter dem indirekten Einfluß der Übersetzungsaktivität des 12. Jahrhunderts (und das aufgrund ganz anderer Bereiche der Physik). Betrachtet man die im 12. Jahrhundert nun neu zugänglichen Werke als ganzes, besteht der überwiegende Teil aus Werken des Aristoteles und seines Kommentators Averroes. Die innere Kohärenz dieses säkularen Corpus, sein begrifflicher Reichtum und seine methodische Stärke, machten ihn innerhalb kürzester Zeit extrem einflußreich und ebenso gefürchtet:

While many theologians and almost all masters of arts eagerly embraced the new Aristotelian learning, there was a growing uneasiness amongst certain more traditionally minded theologians about the course of events. They feared that Christian theology would be undermined not only by Aristotelian ideas that directly conflicted with the Christian faith, such as the eternity of the

\footnotetext{
${ }^{29}$ Zur Geschichte der Optik vgl.: Alistair C. Crombie: The Mechanic Hypothesis and the Scientific Study of Vision. Aus: Crombie: Science, Optics, S. 175-284; David C. Lindberg: The Science of Optics, S. 250-251; ders.: Auge und Licht im Mittelalter: Die Entwicklung der Optik von Alkindi bis Kepler. Frankfurt am Main (Suhrkamp) 1985; ders.: Roger Bacon and the Origins of perspectiva in the West. Aus: Edward Grant, John E. Murdoch (Hrsg.): Mathematics and its applications to science and natural philosophy in the Middle Ages: Essays in honor of Marshall Clagett. Cambridge (Cambridge University Press) 1987, S. 249-268; ders.: Alhazen's Theory of Vision and its Reception in the West. Aus: Lindberg: Studies, S. 321-341 und A. Mark Smith: Getting the Big Picture in Perspectivist Optics. In: Isis, 72. Jg. (1981), S. 568-589.

${ }^{30}$ Lindberg: Roger Bacon, S. 252.
} 
world and the unicity of the intellect, but also by modes of thought that were becoming increasingly naturalistic and deterministic. ${ }^{31}$

Das Mißtrauen schlug sich schließlich in der Verurteilung von 1277 nieder. Schon 1210 untersagte die Provinzialsynode von Sens unter Androhung der Exkommunikation die öffentliche, wie die heimliche Lektüre von Aristoteles' naturphilosophischer Schriften und aller Kommentare dazu ${ }^{32}$. Unter Papst Johannes XXI. verurteilte schließlich der Bischof von Paris, Stephan Tempier, im Jahre 1277 insgesamt 219 Thesen verschiedener Quellen.

Diese Verurteilung hatte zunächst natürlich direkten Einfluß auf die Universität von Paris und die Lehre der verurteilten Sätze. Interessanter für die Wissenschaftsgeschichte scheinen mir aber die Nebenwirkungen zu sein. Einerseits wurde durch den Zusammenstoß eine antiaristotelische Einstellung verstärkt, die zusammen mit neoplatonistischen Strömungen zur Buridanischen Schule ${ }^{33}$ des 14. Jahrhunderts führte ${ }^{34}$. Andererseits schürte diese Entwicklung das Mißtrauen gegen unkritisches deduktives Schließen aus aristotelischen Prinzipien, was im radikalen Empirismus eines Wilhelm von Ockham gipfelte ${ }^{35}$.

Die Wissenschaftler dieses Zeitraums blieben Aristoteles zwar insofern treu ${ }^{36}$, als daß der Verweis auf die Autorität des Philosophen immer noch ein gutes Argument innerhalb einer wissenschaftlichen Erklärung blieb. Aber man suchte zunehmend nach besseren Argumenten (wie experimentum oder experientia), die Aristoteles ersetzten, und wenn eine These des Philosophen der eigenen im Weg stand oder mit der experientia nicht zu vereinbaren war, hatte man keine Schwierigkeiten, Aristoteles explizit zu widerlegen.

\subsection{Der Regenbogen im aristotelischen Corpus}

Die erste wirklich systematische Theorie des Regenbogens findet sich in De Meteorologica von Aristoteles. Ausgestattet mit seiner Autorität wurden die dort dargelegten Problemstellungen, Lösungen und Methoden paradigmatisch für die Behandlung des Regenbogenphänomens bis in die frühe Neuzeit. Die Frage nach der Originalität seiner Theorie außer acht lassend, will ich im folgenden kurz einige der Bestandteile seiner Erklärung erläutern, die im 13. Jahrhundert Verbesserungen erfuhren oder signifikanten Einfluß auf die Lösung Dietrichs von Freiberg hatten.

\footnotetext{
${ }^{31}$ Edward Grant: The condemnation of 1277, God's Absolute Power, and Physical Thought in the Late Middle Ages. Aus: Edward Grant (Hrsg.): Studies in Medieval Science and Natural Philosophy. London (Variorum Reprints) 1981, S. 211. Zu diesem Thema auch Grant: Das physikalische Weltbild, S. $45 \mathrm{ff}$.

${ }^{32}$ Vgl:: Grant: Das physikalische Weltbild, S. 45.

${ }^{33}$ Johannes Buridan, Nicolaus von Oresme, Albert von Sachsen und Thimon Judaeus, die alle in einer deutlichen Tradition stehen und deren Ergebnisse als Gemeinschaftsarbeiten bezeichnet werden können, werden nach ihrem ältesten Mitglied als „Buridanische Schule“ bezeichnet.

34 Vgl.: Carl B. Boyer: The Rainbow: From Myth to Mathematics. Houndsmills, Blasingstoke, Hampshire u. a. (Macmillan) 1987, S. 130-132.

${ }^{35}$ Vgl.: Grant: Das physikalische Weltbild, S. 53-58 und Paul Beckmann: Wilhelm von Ockham. München (Beck) 1995 (= Beck'sche Reihe: Denker), S. 59.

${ }^{36}$ Dies gilt mit Ausnahme der Buridanischen Schule und innerhalb derer insbesondere Thimon, dessen wissenschaftlicher Beitrag teilweise nur darin bestand, das Gegenteil dessen zu behaupten, was Aristoteles vertreten hatte. Vgl.: Boyer: The Rainbow, S. 132: ,[...] Themo seems to be determined to deny whatever Aristotle affirms and to affirm what Aristotle denies. (This is scarcely what one has been taught to expect of the medieval period, with its presumed respect for authority.) “
} 


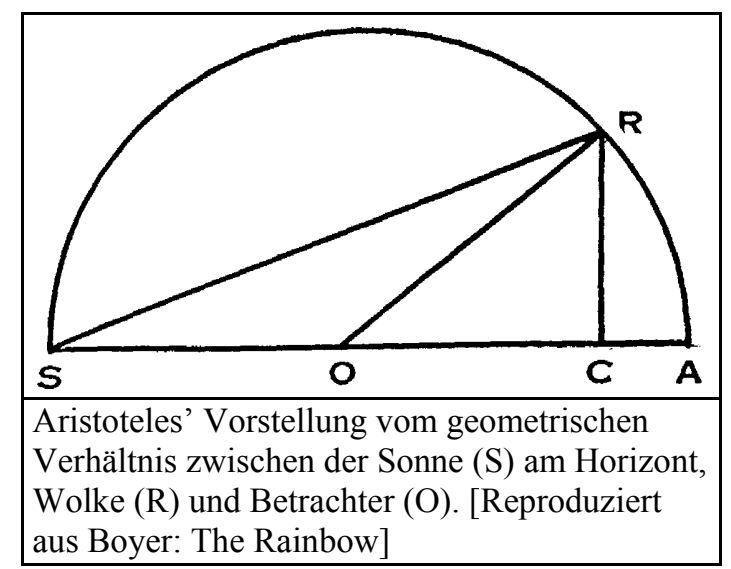

Bereits Aristoteles' Behandlung ist im Grunde geometrisch. Er geht von drei Konstituenten aus, einer Lichtquelle (im Normalfall die Sonne), einer dunklen Regenwolke und dem Auge des Betrachters. Der Regenbogen entsteht durch Reflexion des Sonnenlichtes an einzelnen Regentropfen ${ }^{37}$, die jedoch (nach Aristoteles' zweitem Reflexionsgesetz) zu klein sind, um Formen zu spiegeln, und nur Farben reflektieren. William A. Wallace bemerkt zwar richtig, daß Aristoteles hierdurch die Möglichkeit verschlossen blieb, die Kreisform des Regenbogens auf die Form der Sonne zurückzuführen, allerdings bedeutet das wohl nicht, daß er gar keine Erklärung für die Kreisform geben konnte. ${ }^{38}$ Im Gegenteil hatte wohl Aristoteles bereits verstanden, daß die Kreisform des Regenbogens auf ein grundlegendes geometrisches Verhältnis von Sonne, Wolke und Betrachter zurückzuführen ist. Dieses geometrische Verhältnis, das von Carl B. Boyer ausführlich erläutert wird ${ }^{39}$, ermöglichte es, sowohl eine Erklärung der Frage zu liefern, weshalb der innere Bereich eines Regenbogens nicht erleuchtet ist, als auch die Farbanordnung des Primärregenbogens kohärent einzubinden. Anzumerken ist, daß es in der Theorie des Philosophen notwendigerweise nur drei Farben (von außen nach innen: Rot, Grün und Blau-Violett) im Primärregenbogen gibt und die vierte (Gelb) durch Mischung entsteht. ${ }^{40}$

Inkonsistent wird die aristotelische Theorie durch die Erklärung des zweiten Regenbogens, der bisweilen über dem Primärregenbogen erscheint. ${ }^{41}$ Aristoteles vermutete, daß dieser auf dieselbe Weise wie der Primärregenbogen entsteht, nämlich durch

37 Dies ist in gewisser Weise bereits richtungsweisend für die mikroskopische Behandlung des Regenbogenphänomens im 13. und 14. Jahrhundert. Aristoteles selbst sollte man eine solche Absicht aber noch nicht unterstellen. Vgl. Boyer: The Rainbow, S. 47: „Aristotle, however, did not hit upon the idea of making a geometrical study of what might happen to light which strikes a single drop of rain. He thought of the dewy cloud as a medium which, while not smooth like a mirror, was nevertheless continuos in its parts. It was not an aggregate of discrete droplets, but a unified mass, the component parts of which were cohesive and contiguous."

${ }^{38}$ William A. Wallace: The Scientific Methodology of Theodoric of Freiberg: A Case Study of the Relationship between Science and Philosophy. Fribourg (University Press) 1959 (= Studia Friburgensia. NF 26), S. 135: „He has no explanation for the circular shape of the arc, having eliminated the possibility of the drops reflecting the shape of the sun - which was later to become a popular medieval accounting for the arc."

${ }^{39}$ Boyer: The Rainbow, S. 38-54.

${ }^{40}$ Obwohl diese Auffassung bei Aristoteles kaum begründet wird und vermutlich auf Zahlenmystik zurückzuführen ist, hält sie sich bis ins 14. Jahrhundert.

${ }^{41}$ Man muß dazu anmerken, daß Aristoteles wohl der erste war, der überhaupt einen Erklärungsversuch für den zweiten Regenbogen unternommen hat. Vgl.: Boyer: The Rainbow, S. 50: „The inner or brighter bow is known as the primary rainbow, the outer and less bright is called the secondary. Who first noticed the latter is not known, but the first recorded account of it is that given by Aristotle in his treatise On Meteorology.“ 
Lichtreflexion an einer höheren Stelle der Wolke, von der die Strahlen reflektiert werden, die den ersten Regenbogen bilden. Da die Farbanordnung im zweiten Regenbogen jedoch die umgekehrte Reihenfolge aufweist wie im Primärregenbogen, griff Aristoteles auf ein zweites geometrisches Modell der Farbentstehung zurück, das mit der geometrischen Analyse des ersten Regenbogens nicht vereinbar ist. Aristoteles verstie $\beta$ damit in gewisser Weise gegen sein eigenes Uniformitäts- und Ökonomieprinzip, daß in der Natur alles auf die gleiche, einfachste und beste Weise angelegt sei. ${ }^{42}$ Die Möglichkeit eines dritten Regenbogens wies er zurück, da er für den zweiten Regenbogen aufgrund der größeren Höhe bereits eine starke Schwächung der Strahlen vermutete, die einen weiteren Regenbogen unsichtbar machen würde.

\subsection{Robert Grosseteste (ca. 1168-1253)}

Die Rolle des Bischofs von Lincoln in der Wissenschaftsgeschichte ist oft betont worden $^{43}$, und in der Tat begann mit Robert Grosseteste der Einfluß der griechischarabischen Tradition auf die Wissenschaft des Mittelalters. Er gehörte zu den ersten, denen einige der neuen Übersetzungen zur Verfügung standen, wie Euclids De speculis, Avicennas Liber canonis und De meteorologica sowie De generatione animalium von Aristoteles und vermutlich auch Euclids De visu und Alkindis De aspectibus. Die Kenntnis dieser Schriften hob die Beschäftigung mit den Problemen der perspectiva ohne Zweifel auf ein neues Niveau. Die Tatsache, daß er keinen Zugang zu den wichtigsten Optik-Werken der Antike hatte, wie Ptolemaeus' Optica, oder zu Alhazens De aspectibus, schränkte seine Möglichkeiten jedoch zugleich ein. Er stand zwar am Anfang einer neuen Entwicklung der abendländischen Wissenschaft, aber er war ein „Denker des Überganges“ ${ }^{\text {44 }}$.

Für Grosseteste war die Untersuchung der Optik, der Wissenschaft vom Licht und seiner Ausbreitung, grundlegend für jede Beschäftigung mit Naturphilosophie ${ }^{45}$. Da die Untersuchungsmethode der perspectiva die Geometrie war, wurde hierdurch die Mathematik zu einer noch zentraleren wissenschaftlichen Disziplin ${ }^{46}$ :

The usefulness of considering lines, angles and figures is very great, since it is impossible to understand natural philosophy without them. They are useful in relation to the universe as a whole and its individual parts. [...]

Now, all causes of natural effects must be expressed by means of lines, angles, and figures, for otherwise it is impossible to grasp their explanation. ${ }^{47}$

Aber eine geometrische Behandlung der Optik bedeutete noch nicht Quantifizierung im heutigen Sinn. Grosseteste war zwar der erste, der ein Gesetz der Lichtbrechung

\footnotetext{
${ }^{42}$ Vgl.: Boyer: The Rainbow, S. 52.

${ }^{43}$ Ein Standardwerk ist Crombie: Robert Grosseteste (s.h. auch Alistair C. Crombie: Grossete's Position in the History of Science. Aus: Crombie: Science, Optics, S. 115-137.

${ }^{44}$ Lindberg: Auge und Licht, S. 174. Würde man Grosseteste aufgrund seiner Sehtheorie beurteilen, müßte man ihn zu den Platonisten des frühen Mittelalters rechnen. Wie sehr die Entwicklung der perspectiva in diesem Zeitraum von der Erreichbarkeit der griechisch-arabischen Quellen abhing, wird im folgenden noch deutlich werden.

${ }^{45}$ Lindberg: Auge und Licht, S. 181: „Also heißt die Optik verstehen, die Natur verstehen; und das gilt besonders für die geometrische Optik."“

${ }^{46}$ Vgl.: Alistair C. Crombie: Quantification in Medieval Physics. Aus: Crombie: Science, Optics, S. 73-90.

${ }^{47}$ Robert Grosseteste: Concerning Lines, Angles and Figures. Aus Edward Grant (Hrsg.): A Source Book in Medieval Science. Cambridge, Massachusetts (Harvard Univerity Press) 1974, S. 385.
} 
formulierte, dabei handelte es sich aber mehr um ein qualitatives als um ein quantitatives Gesetz $^{48}$ :

The visual ray penetrating through several transparent substances of diverse natures is refracted at their junctions, and its parts, in the different transparent media existing at those junctions, are joint at an angle. [...]

The amount of divergence from rectilinearity of rays joined at an angle can be represented as follows. Imagine a ray from the eye incident through air on a second transparent medium, extended continuously and rectilinearly [into the second medium], and a line perpendicular to the interface drawn into the depth of the medium from the point at which the ray is incident on the [second] transparent medium. I say, then, that the path of the ray in the second transparent medium is along the line bisecting the angle enclosed by the ray which we have imagined to be extended continuously and rectilinearly and the perpendicular line drawn into the depth of the second transparent medium from the point of incidence of the ray on its surface. ${ }^{49}$

Das Ökonomieprinzip und nicht eine empirische Untersuchung hatte den Bischof von Lincoln vom Reflexionsgesetz zu diesem Gesetz der Lichtbrechung geführt ${ }^{50}$. Erst Witelo griff wieder eine quantifizierende Behandlung des Brechungsgesetzes auf, allerdings seltsam inadäquat, wie ich noch zeigen werde.

Dieses Brechungsgesetz fügte Grosseteste auch in seine Erklärung des Regenbogens ein. Von Aristoteles an wurde das Regenbogenphänomen ausschließlich über

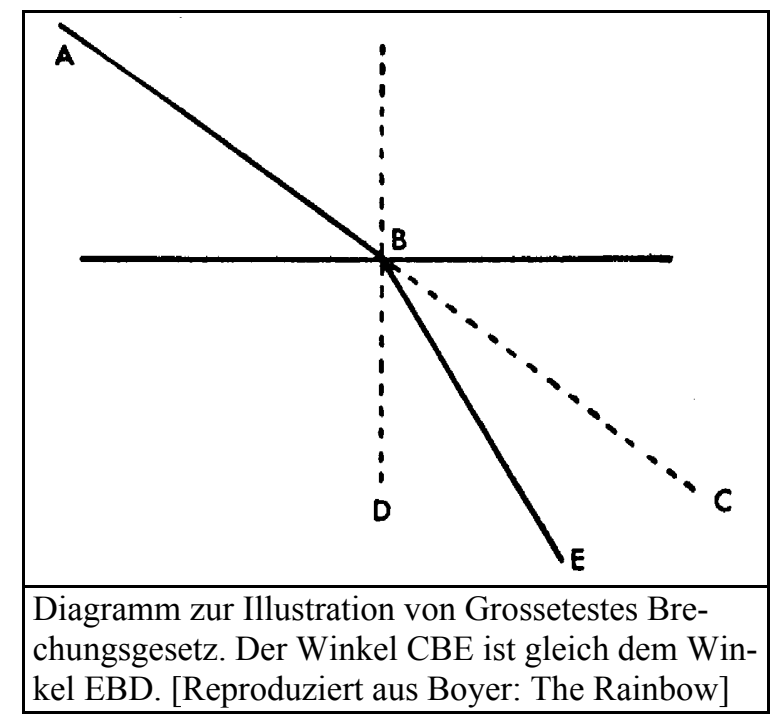

Reflexion erklärt. Aus Sicht der modernen Erklärung könnte man die Einführung des Brechungsbegriffs in die Regenbogentheorie also als Fortschritt betrachten.

Grossetestes Argumentation für die Entstehung des Regenbogens aufgrund mehrmaliger Lichtbrechung verläuft dabei nach mittelalterlichem Muster durch Widerlegung alternativer Erklärungen ${ }^{51}$. Sie beginnt mit dem altbekannten Axiom, daß es drei Weisen gibt, in denen ein Lichtstrahl verlaufen kann: geradlinig, reflektiert oder

\footnotetext{
${ }^{48}$ Zur mittelalterlichen Behandlung des Phänomens der Lichtbrechung vgl:: David C. Lindberg: The Cause of Refraction in Medieval Optics. Aus: Lindberg: Studies, S. 338-368.

${ }^{49}$ Robert Grosseteste: On the Rainbow. Aus: Grant: A Source Book, S. 390.

${ }^{50}$ Vgl.: Bruce S. Eastwood: Grosseteste's „Quantitative“ Law of Refraction: A Chapter in the History of Non-Experimental Science. In: Journal of the history of Ideas, XXVIII. Jg. (1967), S. 403-414 und ders.: Medieval Empiricism: The Case of Grosseteste's Optics. In: Speculum, XLIII. Jg. (1968), S. 306-321.

51 Vgl.: David C. Lindberg: Roger Bacon's Theory of the Rainbow: Progress or Regress? Aus: Lindberg: Studies, S. 243: „The medieval scientist was always more skillful to at falsifying the opposition theory than at verifying his own."
} 
gebrochen $^{52}$. Um nun zu beweisen, daß der Regenbogen durch Lichtbrechung entsteht, beweist er, daß er weder durch geradliniges noch durch reflektiertes Licht verursacht wird. Diese Widerlegungen und auch sein eigener Erklärungsansatz sind sehr schwer verständlich und scheinen nur Sinn zu machen, wenn man Grosseteste unterstellt, daß er den Regenbogen nicht als zum Betrachter umgelenktes Sonnenlicht verstand, sondern als ein reales Ding, das in oder an einer Wolke durch Lichtstrahlen entsteht und dann wie jedes reale Objekt aufgrund der Emanation seiner eigenen species betrachtet werden kann ${ }^{53}$.

Festzuhalten ist, daß Grosseteste den Regenbogen makroskopisch erklärt, über Lichtbrechung, Form und Dichte der Wolke ${ }^{54}$. Er erwähnt zwar zum ersten Mal den Begriff der Lichtbrechung im Zusammenhang mit der Erklärung des Regenbogens und ist gegenüber der aristotelischen Theorie bemerkenswert eigenständig, fällt in der Erklärungsstärke aber hinter sie zurück ${ }^{55}$.

\subsection{Albertus Magnus (ca. 1193-1280)}

War Grossetestes De Iride noch ein kurzes Werk, das auf engem Raum eine neue Theorie präsentierte, findet man bei Albertus Magnus in De Meteoris Libri III (Tractatus $I V$ ) eine ,encyclopedic history of the views of others from Hesiod to his own day." Sein eigener Erklärungsansatz weist gewisse Ähnlichkeiten mit dem von Robert Grosseteste auf $^{56}$, ist aber insofern originell, als daß er die Rolle der einzelnen Regentropfen bei der Bildung des Regenbogens betont ${ }^{57}$. Insbesondere die Farbenbildung wird über die Dichte der Tropfen an den verschiedenen Stellen der Wolke erklärt.

\footnotetext{
${ }^{52}$ Grosseteste: Rainbow, S. 389: „Perspective has three principal subdivisions, according to the triple mode in which rays are transmitted to the visible object. For either transmission of the ray to the visible object is in a straight line through a transparent medium of a single kind interposed between the observer and the object; or in a straight line to a body having spiritual nature which is such as to make it a mirror, from which the ray is reflected to the object; or through several transparent media of different kinds, at the junctions of which the visual rays are refracted to form angles, so that the ray reaches the object not by direct approach but by a path of several straight lines joined at angles."

${ }^{53} \mathrm{Zu}$ dieser Interpretation vgl. Lindberg: Bacon's Theory, S. 239.

Carl Boyer vermutet, daß Grosseteste ein Zusammenspiel von Brechung und Reflexion im Sinn hatte und das letztere nur nicht erwähnte. Das scheint mir aber unwahrscheinlich und zu sehr von der Theorie Witelos heraus gedacht zu sein. Vgl. Boyer: The Rainbow, S. 92: „One can reconcile the passage in the commentary on the Posterior Analytics with the explanation in De Iride by assuming that the solar ray, after undergoing the postulated multiple refractions, impinge upon a distant cloud or other background and are thereby reflected to the eye."

${ }^{54}$ Grosseteste: Rainbow, S. 390 f.: „Therefore, the rainbow must be formed by the [refraction] of solar rays in the mist of a convex cloud. I maintain that the outside of a cloud is convex and the inside concave, as is evident from the nature of light and heavy. [...] Therefore, there are, in all, four transparent media through which a ray of the sun penetrates. [...] By these refractions the rays converge in the density of the mist and, being refracted there once more as from the vertex of a pyramid, spread out not into a round pyramid but into a figure like the curved surface of a round pyramid expanded opposite the sun."

${ }^{55}$ Lindberg: Bacon's Theory, S. 241: „Grosseteste's only significant contribution was to introduce the concept of refraction into the theory of the rainbow; unfortunately he failed to assign refraction its proper role (in the individual drop) or even to explore rigorously the implications of the macroscopic theory he had presented."

${ }^{56}$ Vgl.: Boyer: The Rainbow, S. 95.

${ }^{57}$ Vgl.: Wallace: Theodoric of Freiberg, S. 142: „He [Albertus Magnus] appears, moreover, to have been the first to demonstrate clearly that it is the individual falling drops which produce the rainbow." und Rom Harré: Great Scientific Experiments: Twenty Experiments that changed our View of the World. Oxford, New York (Oxford University Press) 1981, S. 86: „Albertus Magnus first proposed the
} 
Sein Gebrauch des Brechungsbegriffes ist dabei eher unklar, und er scheint Reflexion und Brechung des öfteren zu konfundieren ${ }^{58}$. Bei der Erklärung der Bogenform greift Albert wieder auf die makroskopische Vorstellung zurück und bezieht sich auf die Wolkenform. Sowohl bei der Farbenbildung, als auch bei der Erklärung der Form gibt er aber Hinweise auf mögliche empirische Untersuchungen. Er verweist auf Analogien zwischen ,the cone of moisture in nature and artificial water sprays before the window in a room “59 ${ }^{65}$ und in seiner makroskopischen Erklärung verwendet er eine durchsichtige, mit schwarzer Tinte gefüllte Flasche als Modell.

Man kann von Grosseteste zu Albert also sowohl einen gewissen theoretischen Fortschritt erkennen (was die Betonung der Rolle des einzelnen Regentropfens betrifft) als auch eine methodische Weiterentwicklung zur Beobachtung am Modell, dem Regenbogen im Labor. Allerdings stehen gerade diese grundlegenden Vorstellungen, die ein Vierteljahrhundert nach seinem Tod zur Lösung Dietrichs von Freiberg führten, noch unverbunden nebeneinander.

\subsection{Roger Bacon (ca. 1219-1292)}

Der Doctor mirabilis besaß im Vergleich mit seinen beiden Vorgängern die besten Voraussetzungen, als er sich an die Erklärung des Regenbogens machte. Er kannte nicht nur die Schriften von Robert Grosseteste und Albertus Magnus, sondern hatte auch Zugang zu griechischen und arabischen Quellen (insbesondere zu Ptolemaeus und Alhazen). Hierdurch gelang es ihm, Verbesserungen an Grossetestes Auffassungen vorzunehmen, wie beispielsweise am neuen Brechungsgesetz:

It must be recognized, secondly, that multiplication [of species] is diversified along refracted lines; and refraction occurs in two ways. When the second medium is denser [than the first], refraction of the species at the surface of the second substance takes place between the direct path and the perpendicular extended into the second body from the point of refraction; thus the species deviates from the direct path into the depth of the second body and divides the angle between the direct path and the perpendicular extended into the second body from the point of refraction. Nevertheless, it does not always divide that angle into two equal parts, though some think it does, since greater deviation and less refraction from the direct path occur as a result of different densities of the second medium, according to the various differences in the angles of refraction determined by Ptolemy in Book V of his De aspectibus and Alhazen in his Book VII. ${ }^{60}$ [Hervorhebung von mir, DC]

Grossetestes Versuch, den Regenbogen ausschließlich über mehrmalige Lichtbrechung zu erklären, wies er zurück. Er verfolgte die aristotelische Vorstellung weiter, daß eine Wand kontinuierlich fallender Regentropfen ähnlich einem großen Spiegel die Sonne reflektiert, wobei die Farbe, die im Regenbogen erscheint, von der Dichte der Wolke abhängt.

\footnotetext{
theory that the rainbow was produced by light interacting with each drop." Boyer glaubt hingegen eine mikroskopische Tradition seit Seneca erkennen zu können. Vgl.: Boyer: The Rainbow, S. 96: „In particular, Albert's reiteration of the part played by individual drops was a necessary prelude to any successful assault on the mystery of the rainbow. Seneca's microcosmic reflection theory had survived from antiquity, along its rival, the Posidonian macrocosmic reflection theory. In a sense one can regard Grosseteste as the proponent of the first macrocosmic refraction hypothesis and Albertus as the initiator of the microcosmic refraction doctrine. One should not, of course, carry this distinction too far."

${ }^{58}$ Vgl.: Boyer: The Rainbow, S. 95.

${ }^{59}$ Boyer: The Rainbow, S. 97.

${ }^{60}$ Roger Bacon: The Geometry of Refraction. Aus Grant: A Source Book, S. 423.
} 
Bacon betrachtete den Regenbogen im Gegensatz zu Grosseteste als bloße Erscheinung, da er anders nicht erklären konnte, daß sich der Regenbogen mit dem Betrachter bewegt ${ }^{61}$. Neben der theoretisch gerechtfertigten Kritik an Grossetestes Erklärungsversuch $^{62}$ (bei der die Lichtbrechung allerdings wieder aus der Erklärung verschwand), fügte er der Erforschung des Regenbogens auch neue positive Impulse hinzu. Er betonte die Rolle des Experiments und schlug Beobachtungen an Prismen, versprühtem Wasser, Tautropfen auf Grashalmen, Öl und mit Wasser gefüllten Flaschen vor. Auf der theoretischen Ebene führten ihn seine neuen empirischen Methoden auch zu Ergebnissen:

He also urges the experimenter to take ,the required instrument“" and look through the openings of the instrument and find the altitude of the sun and of the rainbow. Bacon reported that the experimenter will find that the maximum elevation of the Rainbow is $42^{\circ}$. This figure, repeated frequently in the Opus Majus, appears to be the first estimate of the size of the bow; and it is remarkably accurate - so good, in fact, that it was not improved upon until science had reached maturity in the Age of Genius, the seventeenth century. ${ }^{63}$

Weitere theoretische Fortschritte waren die Plazierung der Reflexion im Inneren einer Wolke und die Einsicht, daß der Regenbogen für jeden Betrachter aus einer anderen Gruppe von Regentropfen gebildet wird. Wenn es um die Form des Regenbogens geht, ist jedoch auch Bacons Theorie so makroskopisch wie ihre Vorgänger und verweist auf die Form der Wolke:

When it came to saving his theory, Bacon had no qualms about introducing into his professed microscopic treatment of the cloud, properties characteristic only of concave mirrors considered on a macroscopic scale. That was the price of explaining the rainbow - and too high a price, for it allowed Bacon to be satisfied with an inadequate theory. ${ }^{64}$

Die Spannung zwischen makroskopischer und mikroskopischer Erklärung blieb damit weiterhin ein Problem innerhalb der Regenbogentheorie.

\subsection{Witelo (ca. 1230-?)}

Betrachtet man zunächst Witelos Beitrag zur Erforschung der Lichtbrechung, so zieht mit ihm die experimentelle Quantifizierung in die abendländische Optik ein. Er beschreibt detailliert Alhazens Instrument zur Untersuchung der Lichtbrechung ${ }^{65}$ und

\footnotetext{
61 Wallace scheint Bacon so $\mathrm{zu}$ verstehen, daß er einen prinzipiellen Unterschied zwischen der Lichtbrechung im Prisma und der Farberscheinung im Regenbogen gemacht hätte (die Farben im ersteren seien real, während die im letzteren nur Erscheinungen wären). Diese Interpretation, die für einen methodischen Rückschritt Bacons sprechen könnte, ist aber unvollständig. Bacon hält die Farben des Regenbogens deshalb für bloße Erscheinungen, weil dies gegen Grossetestes Brechungsidee spricht und den Umstand erklärt, daß sich der Regenbogen mit dem Betrachter bewegt, während die Farben am Prisma für jeden gleich seien. Vgl.: Wallace: Theodoric of Freiberg, S. 149.

${ }^{62}$ Vgl.: Lindberg: Bacon's Theory, S. 247: „Bacon by no means offered a satisfactory explanation of all the important phenomena of the rainbow, but [...] Bacon's theory is free of the absurdities that vitiate much of Grosseteste's theory. [...]

I am not arguing therefore, that Bacon gave a correct account of the rainbow - that had to wait for Theodoric of Freiberg, Descartes and Newton - but that he provided a more reasonable account of the principal phenomena than Grosseteste, and an account that contained insights significant for the ultimate development of the correct theory."

${ }^{63}$ Boyer: The Rainbow, S. 100.

${ }^{64}$ Lindberg: Bacon's Theory, S. 246.

${ }^{65}$ S.h. Alhazen: An Instrument for Investigating Refraction. Aus: Grant. A Source Book, S. 420-422.
} 
gibt eine Tabelle mit Winkelmaßen für verschiedene Medien. Obwohl Witelo das Meßinstrument korrekt beschreibt ${ }^{66}$ und zusätzlich behauptet, das Experiment selbst durchgeführt zu haben ${ }^{67}$, sind die Werte falsch und sehr wahrscheinlich nicht auf experimentellem Weg gefunden worden.

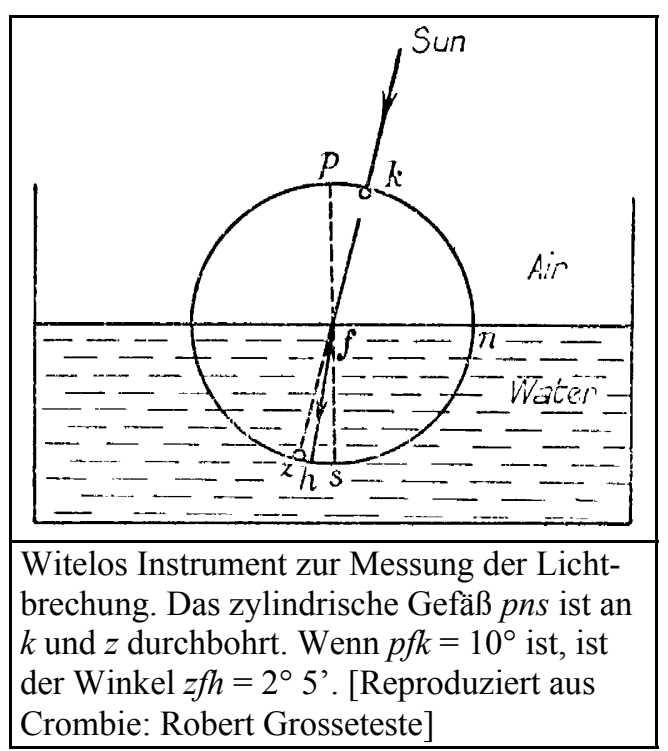

Dennoch wirft dies ein interessantes Licht auf die Entwicklung wissenschaftlicher Methoden. Mit Bacon war die Behandlung des Brechungsgesetzes nicht mehr auf qualitative Art möglich. Ein quantitativer Ansatz mußte erdacht, bzw. in der Tradition gefunden werden, und diesen Ansatz fand Witelo in den Arbeiten Alhazens. Empirische quantifizierende Methoden erstanden so wieder auf, wurden aber noch nicht (oder noch nicht präzise genug) durchgeführt. Ähnliches gilt für Witelos Beobachtung an mit Wasser gefüllten Flaschen, die seit Albertus Magnus, spätestens aber seit Bacon zur Erforschung des Regenbogens gehörten ${ }^{68}$.

Die Wissenschaftler des Mittelalters waren sich des Unterschiedes zwischen experimenteller und mathematischer, bzw. qualitativer Methode wohl bewußt, und innerhalb wissenschaftlicher Erklärungen nahm die Betonung der Empirie zu. Der Verweis auf selbst durchgeführte Experimente bekam langfristig eine stärkere Position als der Verweis auf die Erkenntnisse von Autoritäten. Witelo hätte sich auf Ptolemaeus's Optica beziehen können, aus der er einige der Tabellenwerte übernahm, oder das

\footnotetext{
${ }^{66}$ S.h. Sabetai Unguru: Mathematicas and Experiment in Witelo's Perspectiva. Aus: Grant: Mathematics, S. 269-297 und ders.: Experiment in Medieval Optics. Aus: Sabetai Unguru (Hrsg.): Physics, Cosmology and Astronomy 1300-1700: Tension and Accomodation. Dordrecht, Boston, London (Kluwer) 1991 (= Boston Studies in the Philosophy of Science. 126), S. 163-181.

${ }^{67}$ Vgl.: Witelo: The Geometry of Refraction. Aus Grant: A Source Book, S. 424: „Having observed by means of an instrument as closely as we were able, the angles of all refractions for all known transparent substances $[\ldots]^{\text {“ }}$

${ }^{68}$ Der genaue Nutzen der Beobachtung für die Theorie Witelos ist allerdings unklar. Vgl.: Boyer: The Rainbow, S. 106: „Witelo compared the colors of the bow with those seen when a round glass vase full of water is exposed to the sun's light as the ray pass from air to glass, then glass to water, then water to glass, and finally from glass to air again. But he added cautiously, ,Yet these prismatic colors are not truly like the colors of the rainbow, for the former are seen directly, while the latter are seen by reflection.“ [...] One cannot help wondering whether these ideas were not suggested by Grosseteste's multiple refractions and Bacon's distinction between prismatic and rainbow colors. In any case, Witelo's words seem to have a more modern ring to them, even though one is disappointed by the vagueness of his over-all picture of the rainbow."
} 
qualitative Gesetz angeben, mit dem er einige der falschen Werte berechnete. Statt dessen behauptete er die Durchführung eines kontrollierten Experiments.

Bei Grosseteste stand die qualitative Interpretation der Natur noch deutlich im Vordergrund, bei Bacon begann Empirie neben der Deduktion aus Prinzipien zu stehen, und Witelos Forschung war wiederum ein weiterer Schritt in der Methodengeschichte. Seine theoretischen Erkenntnisse entwickelten sich jedoch nicht proportional zu seinen methodischen Fortschritten.

In seiner Erklärung des Regenbogens griff der filius Thuringorum et Polonorum sowohl auf Lichtbrechung, als auch auf Reflexion zurück. Lichtstrahlen werden zum Teil von der konvexen Außenseite der Regentropfen zum Betrachter reflektiert, andere werden durch Regentropfen gebrochen und erst dann von der konvexen Außenseite dahinter liegender Regentropfen zurückgeworfen. Sowohl Reflexion als auch Brechung sind dabei für Witelo ursächlich bei der Entstehung der Farben. Hier kommen zwar sowohl Brechung, als auch Reflexion innerhalb einer Theorie vor, allerdings sind die Anwendungen der beiden Konzepte auf den Regenbogen so vage, daß man sich hüten muß, zu viel aus der Sicht der korrekten Theorie hinein zu lesen.

Witelo übernahm Bacons Meßergebnisse und griff sowohl den sekundären Regenbogen als auch die Frage nach der Anzahl der Farben wieder auf. Letzteres beantwortete er ganz aristotelisch, und die Autorität scheint hier dann doch noch einmal mehr Gewicht zu haben, als die Beobachtung. Die Farbentstehung im Regenbogen hatte Witelo mit der Lichtbrechung an einer mit Wasser gefüllten Flasche verglichen. Da dabei allerdings vier Farben auftraten, statt der aristotelischen drei, wiederholte er die Baconsche Trennung zwischen Prismenfarben und Regenbogenfarben. Die umgekehrte Reihenfolge der Farben im sekundären Regenbogen führte er im Gegensatz zu Aristoteles auf die Dunkelheit der oberen Wolke zurück ${ }^{69}$. Damit vermied er zwar die aristotelische Inkonsistenz, seine Erklärung wirkt aber wesentlich mehr ad hoc.

Sabetai Unguru hat seine Analyse der Leistungen Witelos für die Optik treffend zusammengefaßt und kommt fast zu den selben Ergebnissen wie meine Analyse der Regenbogentheorie Witelos:

a. There was experiment in medieval optics.

b. There was awareness on Witelo's part of the difference between doing things experimentally and otherwise - mathematically, for instance.

c. „Proving“ things experimentally is not a rarity in optics.

d. Witelo's theory of vision is medieval in spite of his experimental approach (where used).

e. Witelo's „experimental-inductive“ methodology fits snugly in his theory of vision and does not lead to any breakthrough.

f. To have a breakthrough you need a new theory (Kepler), not experiments.

g. As D. C. Lindberg has shown, Kepler's achievement in optics cannot be understood without a thorough understanding of the medieval background from which he grew.

h. The background - including the experiments, for whatever they are worth - is necessary, but obviously not sufficient. $^{70}$

Die Regenbogentheorie erlebte ihren ersten „breakthrough“ jedoch nicht erst mit Kepler, sondern schon kurz nach Witelo mit der Erklärung Dietrichs von Freiberg.

\footnotetext{
${ }^{69} \mathrm{Zu}$ Witelos Regenbogentheorie vgl.: Boyer: The Rainbow, S. 102-107 und Wallace: Theodoric of Freiberg, S. 150.

${ }^{70}$ Unguru: Witelo's Perspectiva, S. 277.
} 


\section{Dietrich von Freiberg}

Dietrich von Freiberg ist eines der bekanntesten Beispiele für erfolgreiches mittelalterliches Forschen. Der deutsche Dominikaner wurde vermutlich um 1250 geboren und hat wohl vor 1272 am Konvent in Freiberg unterrichtet. Danach studierte er an der Univerität von Paris bis 1277. Dietrichs Weggang von Paris und die Verurteilung von 1277 fallen bestimmt nur zufällig zusammen - sicher ist jedenfalls, daß Dietrich von der antiaristotelischen Stimmung an der Pariser Universität nicht unberührt blieb und selbst eher neoplatonischen Auffassungen nachhing.

1293, als Dietrich bereits Bakkalaureus der Theologie war, wurde er zum Provinzialprior der Dominikaner Deutschlands gewählt und blieb dies bis 1296. Er war Teilnehmer des Generalkapitels der Dominikaner in Toulouse 1304, und die letzte Erwähnung Dietrichs findet sich in den Akten des Generalkapitels von Piacenza 1310; wahrscheinlich wird er kurz darauf gestorben sein. In Piacenza wurde der Bologneser Lektor Aymerich zum Ordensgeneral gewählt. Nach Dietrichs eigenem Bericht hat Aymerich ihn damals gebeten, seine revolutionäre Erklärung des Regenbogens niederzuschreiben, was die Datierung der Abfassung von De iride et de radialibus impressionibus auf den Zeitraum zwischen 1304 und 1310/11 ermöglicht. ${ }^{71}$

Durch Paris war er mit den bereits erwähnten Wissenschaftlern zumindest indirekt vertraut; er kannte jedenfalls alle paradigmatischen Probleme, Lösungsansätze und Methoden, auch wenn er sie in seinem Werk nicht immer bestimmten Personen zuordnete. Noch einmal zusammengefaßt war Dietrichs Ausgangssituation die folgende:

Auf methodisch-formaler Ebene wurde seit Aristoteles die Regenbogentheorie geometrisch behandelt. Man führte Beobachtungen am Regenbogen selbst und an ähnlichen optischen Phänomenen durch, insbesondere an Prismen, mit Wasser gefüllten Flaschen und Tautropfen. Es wurden Experimente praktiziert, und man begann den Regenbogen zu vermessen.

Des Unterschiedes zwischen experimenteller und mathematischer Praktik war man sich bewußt, und man kann eine langsame aber stetige Zunahme des Gewichts experimenteller Ergebnisse in den Erklärungen festmachen. Die Übersetzungen, die im 12. Jahrhundert das Abendland erreichten, spielen eher die Rolle eines (wenn auch sehr

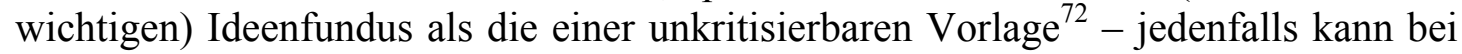
fast allen Beiträgen zur Regenbogentheorie eine gewisse Originalität festgestellt werden.

Auf theoretischer Ebene lag seit Aristoteles die Hauptursache des Regenbogens in Sonnenlicht, das auf Regentropfen trifft. Mit der Zeit rückte die Rolle der einzelnen Regentropfen bei der Bildung des Regenbogens in das Zentrum der Aufmerksamkeit. Aristoteles Spiegelungstheorie wurde spezifiziert, und man führte Lichtbrechung zunächst als alternative Ursache, dann als parallele Ursache in die Theorie ein, ohne jedoch zu einer genauen Vorstellung des stabilen Zusammenwirkens beider Konzepte zu kommen. Die Rolle der Wolken war unklar, wenn sie auch als makroskopische Ursachen für die Reihenfolge der Farben oder die Form des Regenbogens angeführt wurden. Das Verhältnis vom ersten zum zweiten Regenbogen blieb ebenfalls im dunklen und wurde überhaupt nur selten thematisiert. Die Reihenfolge der Farben im

\footnotetext{
${ }^{71}$ Zum Leben Dietrichs von Freiberg vgl.: Loris Sturlese: Dokumente und Forschungen zu Leben und Werk Dietrichs von Freiberg. Hamburg (Meiner) 1984. (= Corpus Philosophorum Teutonicorum Medii Aevi. Beiheft 3); Harré: Great Scientific Experiments, S. 85 und Wallace: Theodoric of Freiberg, S. $10-12$.

${ }^{72}$ Vielleicht muß man „Alhazens Affen“ Witelo hier herausnehmen.
} 
ersten Regenbogen war schon mysteriös, und für die umgekehrte Anordnung im zweiten Regenbogen gab es noch keine mit der restlichen Theorie kohärente Erklärung.

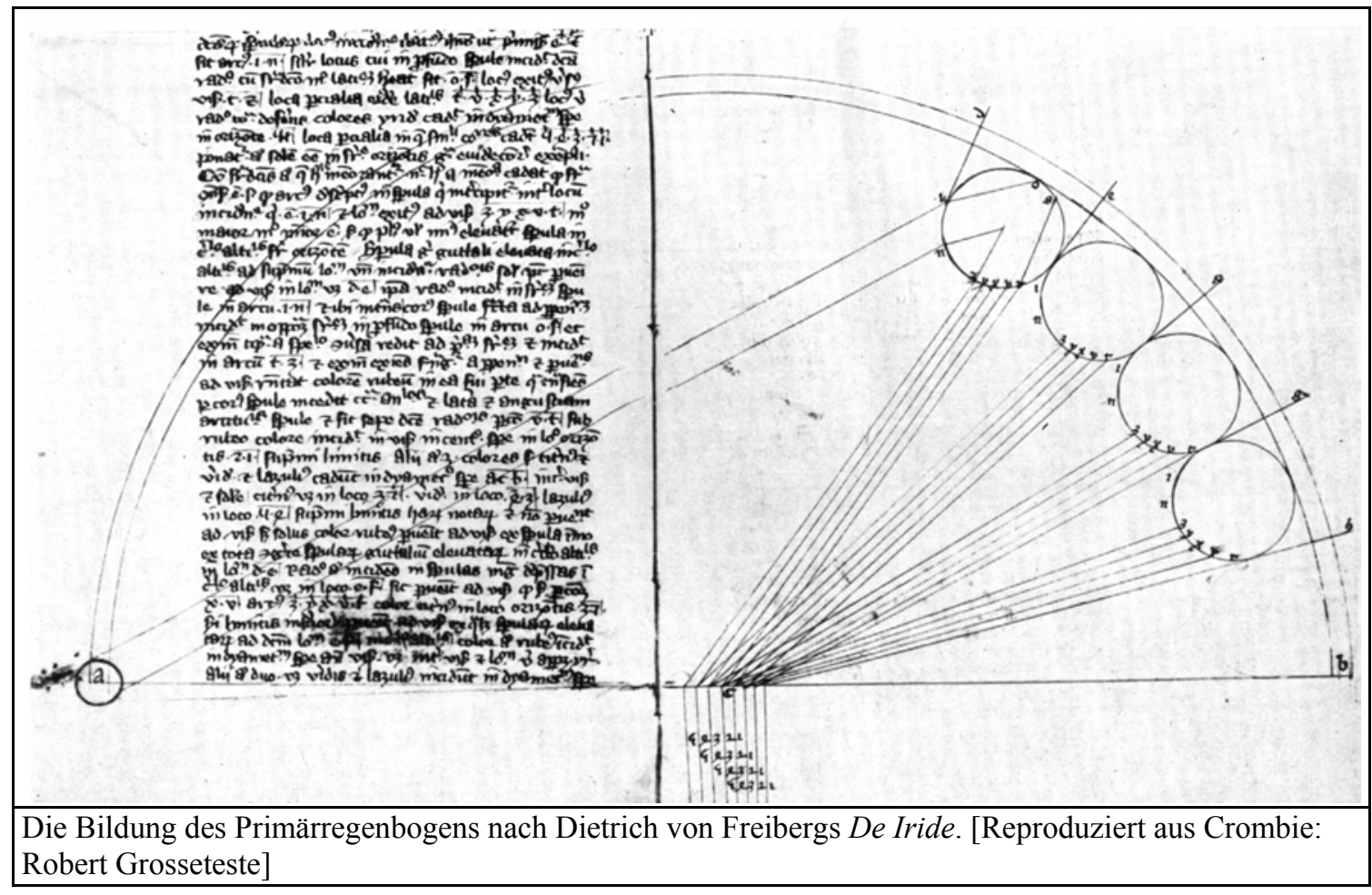

\subsection{Theorie und Methode}

Dietrich von Freiberg ist in der Wissenschaftsgeschichte bekannt dafür, all diese Probleme gelöst und drei Jahrhunderte vor Descartes die richtige Erklärung des Regenbogens gegeben zu haben. ${ }^{73}$ Er habe die Theorie vertreten, daß der primäre Regenbogen durch zweimalige Brechung und Reflexion im einzelnen Regentropfen entsteht. Das auf sphärische Tropfen fallende Licht wird in jedem einzelnen Tropfen gebrochen, an der konkaven Innenseite der Oberfläche reflektiert und beim Austritt wiederum gebrochen. Jede Farbe entsteht dabei in einem anderen Winkel, und das Auge nimmt alle vier Farben gleichzeitig aus vier verschiedenen Reihen von Tropfen wahr. Die Höhe des Regenbogens ist $22^{\circ}$ (in Abweichung der nahezu korrekten $42^{\circ}$ von Roger Bacons Messung); unterhalb derer erfolgt in den Tropfen eine gewisse Lichtbündelung, oberhalb keine Reflexion zum Betrachter mehr, was sowohl die Helligkeit im Innern des Regenbogens als auch die Dunkelheit des Bandes zwischen Haupt- und Nebenregenbogen erklärt.

Der Nebenregenbogen wird auf ähnliche Weise wie der Hauptregenbogen erzeugt, mit dem Unterschied, daß hier das Licht zweimal reflektiert wird und sich somit die Farbreihenfolge umkehrt. Die Höhe des Nebenregenbogens relativ zum Hauptregenbogen ist mit $11^{\circ}$ angegeben und erneute Lichtbündelung bei Überschreitung dieses Wertes die Erklärung für die Weißlichkeit der oberen Wolke.

\footnotetext{
${ }^{73}$ Vgl.: John Losee: A historical Introduction to the Philosophy of Science. Oxford (Oxford University Press) 1993, S. 35-36; Harré: Great Scientific Experiments, S. 84-94; Lindberg: Science of Optics, S. 362; Wallace: Theodoric of Freiberg; Crombie: Robert Grosseteste, 233-259; ders.: Von Augustinus bis Galilei, S. 106-109 und Boyer: The Rainbow, S. 110-124.
} 
Die Entdeckung, die diese vereinheitlichende Theorie hervorbrachte, soll Dietrich mit Hilfe von Experimenten an Regentropfenmodellen gemacht haben. Er habe kugelförmige, mit Wasser gefüllte Glasgefäße (Crombie vermutet eine „Urinflasche, wie man sie zu medizinischen Zwecken benutzte") und eine Kristallkugel für Experimente benutzt, und mit ihnen nicht nur die Reflexion an der konkaven Innenseite, sondern auch die Farbanordnung (in Primär- und Sekundärbogen) sowie den Abstand von $11^{\circ}$ zwischen den beiden Bögen gefunden. ${ }^{74}$

Aufgrund der verbesserten Edition der De Iride-Handschriften ${ }^{75}$ sind von Loris Sturlese an zwei entscheidenden Stellen Einwände gegen diese Interpretation erhoben worden $^{76}$. Sturlese kann keinen Anhaltspunkt für Experimente an irgendwelchen mit Wasser gefüllten Glasgefäßen finden, und die Beobachtungen an soliden Kristallkugeln hätten an den Stellen, an denen sie in der Erklärung Dietrichs vorkommen, nicht die Rolle eines Modells für Regentropfen. Die ausschlaggebenden Untersuchungen seien vielmehr Experimente an Tautropfen gewesen. Zweitens habe Dietrich den Unterschied zwischen Haupt- und Nebenregenbogen nicht, wie später Descartes, an der Anzahl der Reflexionen, sondern an der Weite des Ablenkungswinkels festgemacht $^{77}$.

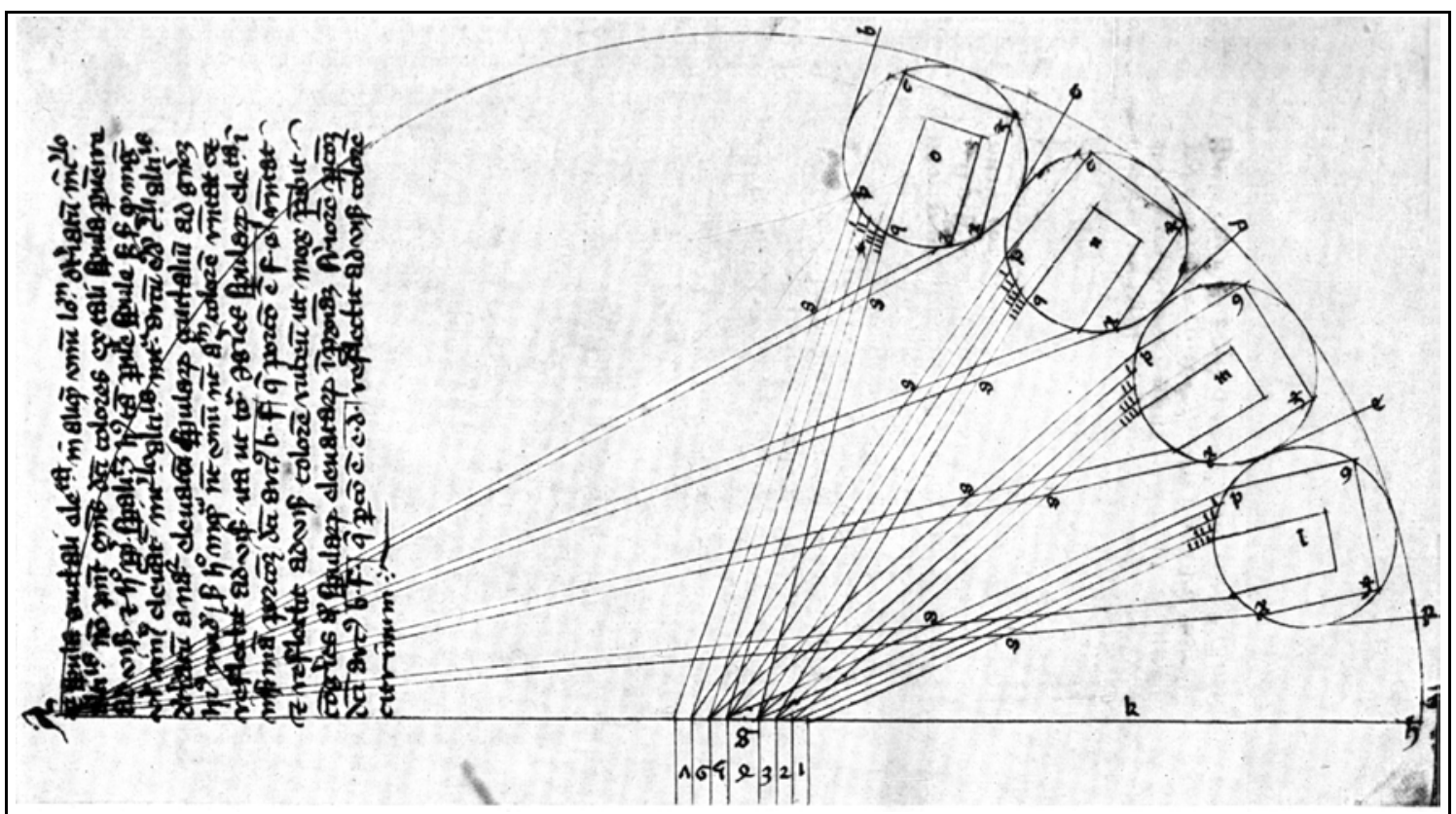

Die Bildung des Sekundärregenbogens nach Dietrich von Freibergs De Iride. Das Diagramm scheint deutlich für die Reflexionsinterpretation zu sprechen. [Reproduziert aus Crombie: Robert Grosseteste]

Um eine detaillierte Auseinandersetzung mit Sturleses Argumentation zu liefern ist hier zu wenig Raum, daher will ich nur kurz auf seine Position eingehen. Zur Reflexion/Ablenkungswinkel-Problematik schreibt Sturlese selbst, die Reflexionsinterpretation habe ,ein gewisses Fundament im Text ${ }^{678}$, und in der Tat kann man ohne sie die Diagramme Dietrichs gar nicht und seine an Aristoteles orientierte geometrische

\footnotetext{
${ }^{74}$ Vgl.: Crombie: Von Augustinus bis Galilei, S. 107.

${ }^{75}$ Dietrich von Freiberg: De iride et de radialibus impressionibus. Aus: Maria R. Pagnoni-Sturlese, Rudolf Rehn, Loris Sturlese, u. a. (Hrsg.): Opera Omnia. Tomus IV. Schriften zur Naturwissenschaft. Briefe. Hamburg (Meiner) 1985. (= Corpus Philosophorum Teutonicorum Medii Aevi. II, 4).

${ }^{76}$ Loris Sturlese: Einleitung. Aus: Pagnoni-Sturlese/Rehn/Sturlese: Opera Omnia, S. XIII-XLV.

${ }^{77}$ Sturlese: Einleitung, S. XXX-XXXIV.

${ }^{78}$ Sturlese: Einleitung, S. XXXII.
} 
Analyse nur sehr schwer interpretieren. Interessanter als diese Frage ist aber Sturleses Kritik an der bisherigen Interpretation der experimentellen Methode des Freiberger Wissenschaftlers.

Rom Harré führt Dietrich in seinem Kapitel über „,The Use of Models to Simulate an otherwise Unresearchable Process“" an. Solche Modell-Experimente beschreibt er folgendermaßen:

But there are processes that are remote from observation or experimental manipulation. Yet they may have a key role in the production of a puzzling natural effect. To deal with cases like this scientists create physical models of the systems involved in the process they are studying; by manipulating the model and seeing how it behaves they infer corresponding processes in the real thing. One of the earliest and most satisfying uses of models in experiment was made by Theodoric of Freibourg, when he used glass globes to simulate the role of raindrops in the formation of the rainbow. ${ }^{79}$

Doch scheint mir Sturleses Kritik diese Interpretation nicht substantiell zu widerlegen. Zunächst einmal ist es offensichtlich, daß Dietrich als einer der ersten die Frage nach den Dispersionsfarben ,,aufgrund einer quasi-systematischen Reihe artifiziell verursachter Dispersionsphänomene “80 anging und daß er Experimente anhand verschiedener brechender Körper (sechskantiger Bergkristall, eine kleine geschliffene Kristallkugel, eine größere Kristallkugel und Tautropfen) anstellte. Klar ist auch, daß er diese zum Teil als Modell für Regentropfen verwendete, wie zum Beispiel nach seiner Erläuterung der unterschiedlichen Weisen, in denen Haupt- und Nebenregenbogen gebildet werden:

(2) Modus autem iste dictae radiationis experimento percipitur, si quis lapidem crystallinum sphaericum, quem beryllum vocant, vel aliquam guttulam claram sphaericam sic aptet ad solem et visum, visu videlicet existente inter solem et talem sphaeram consistentem lateraliter a linea recta incidente a sole visum. Sed haec hactenus in generali. ${ }^{81}$

Dietrich erforschte den Regenbogen tatsächlich zu großen Teilen im Labor, eine deutliche, wenn auch nicht revolutionäre Weiterentwicklung der Methode experimenteller Forschung. Sturleses Kritik macht sicherlich einige Modifikationen in der Interpretation der Dietrichschen Regenbogentheorie vonnöten, substantiell widerlegen kann sie sie aber wohl nicht.

Bei Dietrichs Behandlung der Farbanzahl im Regenbogen erkennt man ebenfalls die bereits zuvor aufgewiesene zunehmende Betonung der Beobachtungsdaten, die der Autorität mit der Zeit den Rang abliefen und hier sogar recht deutlich vorgezogen wurden:

(4) Sed dicendum ad hoc, quod pro reverentia et auctoritate philosophicae doctrinae dictum Philosophi exponendum est, et interpretur quilibet, sicut et potest. Scimus autem, quod secundum eundem Philosophum manifeste secundum sensum nequaquam recedendum est. ${ }^{82}$

Dietrichs Methode steht innerhalb der Tradition der jungen mittelalterlichen perspectiva. Diejenigen Experimente, die bei seinen Vorgängern noch nicht durchgeführt wurden, gehören zum „breakthrough“, der durch seine vereinheitlichende Theorie erreicht wurde. Die theoretische Änderung (Beschränkung der Untersuchung auf die einzelnen Regentropfen) gab diesen Experimenten erst Sinn. Die Theorie selbst ist

\footnotetext{
${ }^{79}$ Harré: Great Scientific Experiments, S. 84.

${ }^{80}$ Sturlese: Einleitung, S. XXXV.

${ }^{81}$ Dietrich von Freiberg: De Iride, S. 223.

${ }^{82}$ Dietrich von Freiberg: De Iride, S. 146.
} 
von weit höherer Qualität als ihre Vorgänger, dennoch lassen sich auch hier Kontinuitäten feststellen. Auf die Herkunft der Hauptideen (geometrisches Verhältnis Sonne-Wolke-Betrachter, Erklärung durch Reflexion, Erklärung durch Brechung, die Rolle des einzelnen Regentropfens, Zusammenfassung von Reflexion und Brechung usw.) bin ich schon eingegangen, Dietrichs theoretische Hauptleistung liegt in der Vereinheitlichung der verschiedenen Einzelideen. ${ }^{83}$

Waren Dietrichs experimentelle Methoden auch 'modern', vermutlich sogar nicht sehr viel schlechter als die von Descartes (und wenn, dann nur graduell schlechter), so ist die theoretische Tradition, in der Dietrich sich bewegte, zwar zum einen der Weg $\mathrm{zu}$ seinem Erfolg, was die Bereitstellung der Hauptideen angeht, zum anderen aber auch die Grenze seiner theoretischen Möglichkeiten: eine Grenze, die erst von Descartes überschritten wurde, nachdem es um den Regenbogen sehr lange sehr still geworden war.

\subsection{Optik und Regenbogen bis Descartes}

Nach einer solchen Forschungstradition, die man durch das gesamte 13. Jahrhundert verfolgen kann, erwartet man in irgendeiner Form den Anschluß der nachfolgenden Wissenschaftler an die erbrachten Leistungen. Interessanterweise blieb er fast völlig aus. Grosseteste, Albert, Bacon und Witelo hatten eine gewisse Nachwirkung, aber die Theorie Dietrichs wurde fast gar nicht rezipiert ${ }^{84}$. Die überlieferten Arbeiten seiner Vorgänger förderten zunächst auch keinen zweiten solchen Versuch. Erst im 16. Jahrhundert gab es eine Annäherung von Maurolycus und Anfang des 17. Jahrhunderts eine weitere von Marco Antonio de Dominis. Das gesamte Problem, das ein ganzes Jahrhundert lang die Wissenschaft beschäftigt hatte, wurde nicht mehr ernsthaft verfolgt. Zwischen Dietrich und Descartes gab es praktisch keinen Fortschritt:

In the period between Descartes and Theodoric we then saw little change in the procedures of investigation employed, although we found that all of the researchers whom we examined did work of a quality inferior to that of Theodoric. [...] [W]e gave some indications from which one could infer a certain and definite influence on Jodocus Trutfetter, an almost certain one on Berthold of Mosburg and Joannes Cronisbenus, a probable one on Maurolyco and De Dominis, and a doubtful one on Thema Judaei. ${ }^{85}$

Die Gründe dafür sind nicht einfach zu bestimmen. Sicher scheint, daß durch das aristotelische Monopol, das an den Universitäten entstand, die Perspektivisten verdrängt wurden. Es gab in den Bildungsinstitutionen einen Interessenwechsel, weg von Themen wie Strahlengeometrie zu solchen wie Strahlungsontologie. Diese Verschiebung führte zur Mittelmäßigkeit aller Versuche an geometrischen oder verwandten Themen $^{86}$. Die Hauptaufmerksamkeit richtete sich einfach auf etwas anderes, etwas neues

\footnotetext{
${ }^{83}$ Ein weiteres Beispiel hierzu ist der mittelalterliche Mechanismus, bei dem zwei Wolken den Regenbogen verursachen (wobei die zweite die Funktion eines Reflektors oder Schirmes besitzt). Dietrich reduziert ihn auf den Vorgang in nur einer Ansammlung von Regentropfen. Dabei geschieht diese Reduktion ganz bewußt und wird im Sinne des Ökonomieprinzips von Dietrich auch als Fortschritt gedeutet. Vgl.: Dietrich von Freiberg: De Iride, S. 188.:

(16) Est etiam superfluum ponere tales duas nubes, ut dicunt, cum una ipsarum sola posita, scilicet rorida, in debito situ ad solem et visum ab ipsa possit immediate fieri reflexio solaris radiationis ad visum et omnia apparentia salva sint, ut infra ostendetur.

${ }^{84}$ Vgl.: J. F. Scott: The Scientific Work of René Descartes (1596-1650). London (Taylor \& Francis) 1976, S. 72.

${ }^{85}$ Wallace: Theodoric of Freiberg, S. 290.

${ }^{86}$ Vgl.: Lindberg: Auge und Licht, S. 258.
} 
- es entstand eine Lücke in der theoretischen Tradition. Da die Fragen der Strahlungsontologie bald keine progressive Problemverschiebung mehr zuließen, setzte sich diese Richtung auch bald methodisch schachmatt - man befand sich in einer Forschungssackgasse.

Der erste wieder Fortschritte erzielende Versuch in der Regenbogentheorie war der von René Descartes, dessen Experimente sich qualitativ nicht von denen Dietrichs unterschieden ${ }^{87}$. Seine Experimente waren geradezu klassisch mittelalterlich, und seine Mathematik vielleicht sorgfältiger, aber immer noch dieselbe Mathematik ${ }^{88}$. Die entscheidenden Unterschiede bestanden vielmehr auf der theoretischen Ebene. Zum einen in der Kenntnis des Brechungsgesetzes, das Descartes die Berechnung der geometrischen Verhältnisse vereinfachte und die Beobachtungen mit der Theorie in Einklang brachte ${ }^{89}$. Zum anderen im aristotelischen Grundmodell, das Dietrich als schon paradigmatischen Bestandteil aus der Tradition übernommen hatte und das von Descartes nicht mehr zugrundegelegt wurde. Die Sonnenstrahlen verlaufen in seinen Diagrammen immer parallel zur Verbindungslinie Sonne-Auge, während sie bei Dietrich immer divergierend gezeichnet sind.

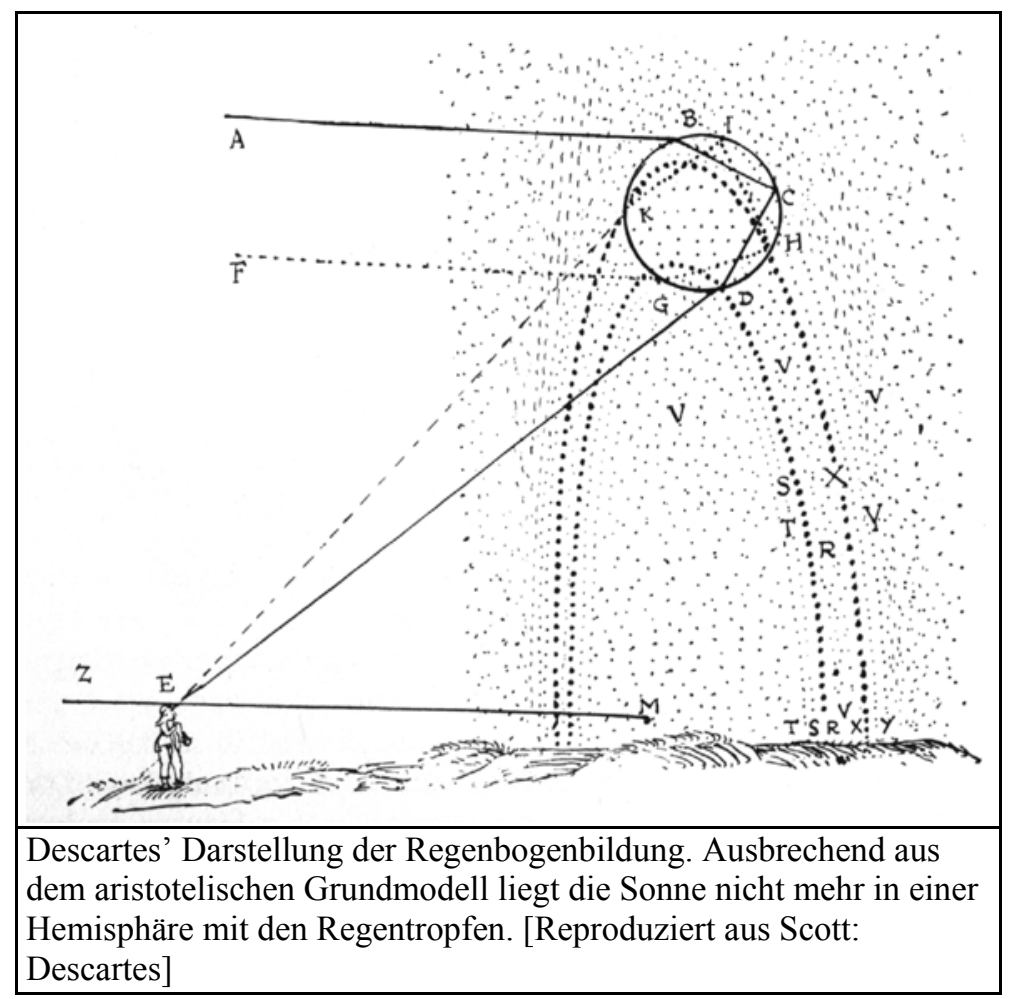

Hier wurde wirklich aus einer Tradition ausgebrochen ${ }^{90}$ : Die Sonne wurde unendlich weit entfernt und nicht mehr innerhalb der aristotelischen Hemisphäre gedacht. Eine Neuerung, die wiederum theoretischer Art war, nicht methodischer ${ }^{91}$.

\footnotetext{
${ }^{87}$ Vgl.: Boyer: The Rainbow, S. 209: „Descartes believed, apparently, that he was the first one thus to study the rainbow experimentally; but we now realize how mistaken he was in this. He was but repeating the observations which Theodoric and Kamal al-Din had made long before, and he drew the conclusions his predecessors had reached."

${ }^{88}$ Vgl.: Alistair C. Crombie: Some Aspects of Descartes’ Attitude to Hypothesis and Experiment. Aus: Crombie: Science, Optics, S. 419-428.

${ }^{89}$ Vgl.: Scott: Descartes, S. 74.

${ }^{90}$ Wesentlich kritischer sieht das William Wallace, der Descartes keine überzeugenden Fortschritte bescheinigt. Vgl.: Wallace: Theodoric of Freiberg: „Examining in detail the extent of Descartes'
} 


\section{Ergebnisse}

Ich habe mich in dieser Untersuchung auf nur einen Wissenschaftszweig, nämlich die geometrische Optik, und dabei wiederum nur auf die Erklärung des Regenbogenphänomens beschränkt. Man könnte einwenden, daß eine so verengte Betrachtung nicht ausreicht, um eine adäquate Beschreibung des Verhältnisses von mittelalterlicher zu moderner Forschung geben zu können. Dem will ich zwei Dinge entgegenhalten.

1) Die Fragen, mit denen ich mich zentral beschäftigte, waren Probleme, die sich aus den Thesen Rossis ergaben. Diese Thesen besitzen einen allgemeinen Charakter und sind inhaltlich nicht auf bestimmte Wissenschaftszweige beschränkt. Der Reihe nach begründe ich meine Einsprüche gegen seine Argumentation folgendermaßen:

Wie ich bereits in 1.1 bemerkte, hängt die Frage nach den naturphilosophischen Denkschranken des Mittelalters mit der Frage nach Experimenten unter künstlich geschaffenen Bedingungen zusammen. Wie ich gezeigt habe, entwickelte sich in der mittelalterlichen perspectiva eine Tradition, die solche Experimente entwickelte, verfeinerte und durchführte. Diese methodische Tradition ist es auch, die in der modernen Wissenschaft wieder unverändert aufgegriffen wurde. Ich habe für Descartes bereits darauf hingewiesen und für Newtons Prisma gilt das gleiche ${ }^{92}$. Der Regenbogen ist ein Phänomen, dem man sich mit Erfahrungen aus der alltäglichen Lebenswelt nur begrenzt nähern konnte. Ab einem bestimmtem Punkt war die Erforschung nur noch unter künstlich geschaffenen Bedingungen möglich, und dieser Schritt wurde im Mittelalter vollzogen.

Was Rossis Befund der „,kodifizierten Regeln“ betrifft, nach denen der mittelalterliche Forscher seine Probleme beharrlich auslotete, ist die Antwort nicht ganz so einfach. Wenn man darunter eine theoretische Fixiertheit versteht, dann gilt das nicht für den betrachteten Zeitraum, da die perspectiva durch die neuen Übersetzungen kaum stabile Paradigmata hatte. Von Grosseteste bis Dietrich finden immer wieder theoretische Neuerungen fundamentaler Art statt. Bevor sich solche Paradigmata hätten etablieren können, wandte sich bereits das Interesse vom Regenbogen ab. In der Astronomie kommt es dagegen im Mittelalter zu solchen Paradigmata, und sie werden tatsächlich in der Wissenschaftlichen Revolution aufgebrochen - aber wir reden dann von theoretischen Revolutionen, deren Ergebnis eine neues Paradigma ist, das wiederum aus kodifizierten Regeln besteht. Ein solches Beispiel für die Optik stellt vielleicht Descartes' Ausbruch aus der aristotelischen Hemisphäre dar, die als harter Kern der mittelalterlichen Regenbogentheorie gewissen paradigmatischen Charakter besaß.

Will Rossi hingegen auf einen methodischen Konservativismus des Mittelalters hinaus - und das scheint mir wahrscheinlicher -, dann muß man feststellen, daß sich wissenschaftliche Methoden mehr oder weniger kontinuierlich von der Antike über

contribution, however, we found that the boast of the French philosopher was not justified. His explanation of the formation of the primary and secondary bows was more correct in some mathematical details than that of Theodoric, but the main lines of his reasoning and the experimentation he used to substantiate it were already present in the optical tradition. His explanation of the origin of radiant color, moreover, was completely erroneous, and revealed the basic defect in his method, namely, that of relying on a subjective, rationalistic norm of certitude, instead of continually referring his judgments to the facts established in sense experience."

${ }^{91}$ Vgl.: Boyer: The Rainbow, S. 119 und Sturlese: Einleitung, S. XXXIX f.

${ }^{92}$ Vgl.: Kuhn: Mathematische versus experimentelle Tradition, S. 96: „Das Prisma, das Newton kaufte, um „die berühmte Erscheinung der Farben“ zu untersuchen, leitete sich von mittelalterlichen Experimenten mit wassergefüllten Kugeln her.“ 
das Mittelalter bis heute weiterentwickelten (und zwar hin zu größerer Präzision, „absoluter Genauigkeit“). Sei es in der Art der Anwendung der Mathematik oder in der experimentellen Forschung, es ist kein qualitativer Bruch während der Wissenschaftlichen Revolution zu erkennen. Die Wissenschaftliche Revolution war eine Revolution in der Betrachtung bekannter Phänomene. Neue Experimente wurden unter Umständen durch solche Betrachtungswechsel entwickelt, weil sie erst jetzt sinnvoll waren. Aber das Experiment an sich wurde nicht neu oder jetzt erst erfunden ${ }^{93}$. Die Regeln waren vorher genauso sehr oder genauso wenig kodifiziert wie nach der Revolution.

Rossis Bild von der modernen Wissenschaft, als „Erforschung eines neuen Kontinents" gilt vielleicht für jeweils recht kurze Zeiträume während der Revolution oder innerhalb einer Krise, wie ich in 1.2 schon zeigte, aber nicht für ihren weiteren Verlauf. Auch eine prinzipielle Autoritätshörigkeit kann man dem mittelalterlichen Wissenschaftler nicht unterstellen. Ich habe auf Entwicklungen hingewiesen, in denen der Verweis auf Autoritäten in wissenschaftlichen Erklärungen zunehmend durch bessere Argumente ersetzt wurde. Insoweit scheint die Beschränkung auf die Optik durchaus ausreichend zu sein, Rossis Thesen in Frage zu stellen.

2) Wie ich im zweiten Abschnitt schon bemerkte, ist die Optik eine Wissenschaft, die im Mittelalter bereits in einer Weise existierte, die sie mit der Optik der Moderne überhaupt erst vergleichbar macht. Die Baconschen Wissenschaften entstanden tatsächlich durch methodische (insbesondere technische) Neuerungen und ähnelten für einen gewissen Zeitraum der „Erforschung eines neuen Kontinents“. Hier hatten neue Experimente eine wesentlich fundamentalere Bedeutung, da sie überhaupt erst den Gegenstandsbereich erschufen. Wenn man aber mittelalterliches Forschen mit modernem vergleichen will, ist es wohl ratsam eine Wissenschaft als Beispiel zu wählen, die in beiden Zeiträumen sinnvoll eingrenzbar existiert, und das ist bei der Optik im Gegensatz zu den Baconschen Wissenschaften der Fall.

Die Ergebnisse, die ich insgesamt aus meiner Untersuchung ziehe, sprechen für die Theorie einseitiger Kontinuität ${ }^{94}$. Man kann relativ konstante Methodenentwicklung feststellen, während auf der theoretischen Ebene große Lücken (der Verlust der Ergebnisse Dietrichs von Freiberg für die weitere theoretische Entwicklung, eine lange Phase ohne erkennbaren Fortschritt bis Descartes) und theoretische Sprünge (Dietrich im Vergleich zu seinen Vorgängern, Descartes' Ausbruch aus der aristotelischen Hemisphäre) den historischen Verlauf bestimmten. Es gibt starke Diskontinuitäten in der Wissenschaftsgeschichte, und es gibt auch eine Wissenschaftliche Revolution - aber nicht da, wo die Katastrophentheorie sie vermutet.

\section{Daniel Cohnitz}

Lehrstuhl für Theoretische Philosophie

Heinrich-Heine-Universität Düsseldorf

cohnitz@phil-fak.uni-duesseldorf.de

http://www.phil-fak.uni-duesseldorf.de/thphil/cohnitz

\footnotetext{
${ }^{93}$ Vgl.: Kuhn: Mathematische versus experimentelle Tradition, S. 97: „Die Wandlung der klassischen Wissenschaften in der Wissenschaftlichen Revolution ist besser neuen Sichtweisen gegenüber alten Erscheinungen zuzurechnen als einer Folge unerwarteter experimenteller Entdeckungen.“

${ }^{94} \mathrm{Vgl}$. Abschnitt 1.1 C).
} 


\section{Literatur}

\section{Primärquellen:}

AlHAZEN: An Instrument for Investigating Refraction. Aus: Grant, Edward (Hrsg.): A Source Book in Medieval Science. Cambridge, Massachusetts (Harvard University Press) 1974. S. 420-422.

Roger BACON: The Geometry of Refraction. Aus: Grant, Edward (Hrsg.): A Source Book in Medieval Science. Cambridge, Massachusetts (Harvard University Press) 1974. S. 423-424.

Dietrich von Freiberg: De iride et de radialibus impressionibus. Aus: PagnoniSturlese, Maria R.; Rehn, Rudolf; Sturlese, Loris; u. a. (Hrsg.): Opera Omnia. Tomus IV. Schriften zur Naturwissenschaft. Briefe. Hamburg (Meiner) 1985. (= Corpus Philosophorum Teutonicorum Medii Aevi. II, 4) 115-268.

Dietrich Von Freiberg: On the Rainbow. Aus: Grant, Edward (Hrsg.): A Source Book in Medieval Science. Cambridge, Massachusetts (Harvard University Press) 1974. S. 435-441.

Robert Grosseteste: Concerning Lines, Angles and Figures. Aus: Grant, Edward (Hrsg.): A Source Book in Medieval Science. Cambridge, Massachusetts (Harvard University Press) 1974. S. 385-388.

Robert Grosseteste: On the Rainbow. Aus: Grant, Edward (Hrsg.): A Source Book in Medieval Science. Cambridge, Massachusetts (Harvard University Press) 1974. S. 388-391.

Witelo: The Geometry of Refraction. Aus: Grant, Edward (Hrsg.): A Source Book in Medieval Science. Cambridge, Massachusetts (Harvard University Press) 1974. S. 424-426.

\section{Literatur}

BecKmann, Paul: Wilhelm von Ockham. München (Beck) 1995. (= Beck'sche Reihe: Denker)

BOYer, Carl B.: The Rainbow: From Myth to Mathematics. Houndsmills, Blasingstoke, Hampshire u. a. (Macmillan) 1987.

CHARPA, Ulrich: Philosophische Wissenschaftshistorie. Grundsatzfragen / Verlaufsmodelle. Göttingen (Viehweg) 1995. (=Wissenschaftstheorie, Wissenschaft und Philosophie. 42)

Crombie, Alistair C.: Robert Grosseteste and the Origins of Experimental Science 1100-1700. Oxford (Clarendon Press) 1971.

Crombie, Alistair C.: Von Augustinus bis Galilei: Die Emanzipation der Naturwissenschaft. München (dtv) 1977.

Crombie, Alistair C. (Hrsg.): Science, Optics and Music in Medieval and Early Modern Thought. London (Hambledon Press) 1990.

Crombie, Alistair C.: The Relevance of the Middle Ages to the Scientific Movement. Aus: Crombie, Alistair C. (Hrsg.): Science, Optics and Music in Medieval and Early Modern Thought. London (Hambledon Press) 1990. S. 41-71. 
Crombie, Alistair C.: Quantification in Medieval Physics. Aus: Crombie, Alistair C. (Hrsg.): Science, Optics and Music in Medieval and Early Modern Thought. London (Hambledon Press) 1990. S. 73-90.

Crombie, Alistair C.: Grosseteste's Position in the History of Science. Aus: Crombie, Alistair C. (Hrsg.): Science, Optics and Music in Medieval and Early Modern Thought. London (Hambledon Press) 1990. S. 115-137.

CrombIE, Alistair C.: The Significance of Medieval Discussions of Scientific Method for the Scientific Revolution. Aus: Crombie, Alistair C. (Hrsg.): Science, Optics and Music in Medieval and Early Modern Thought. London (Hambledon Press) 1990. S. 139-160.

Crombie, Alistair C.: The Mechanic Hypohesis and the Scientific Study of Vision. Aus: Crombie, Alistair C. (Hrsg.): Science, Optics and Music in Medieval and Early Modern Thought. London (Hambledon Press) 1990. S. 175-284.

Crombie, Alistair C.: Some Aspects of Descartes' Attitude to Hypothesis and Experiment. Aus: Crombie, Alistair C. (Hrsg.): Science, Optics and Music in Medieval and Early Modern Thought. London (Hambledon Press) 1990. S. 419-428.

CrombIE, Alistair C.: What is the History of Science? Aus: Crombie, Alistair C. (Hrsg.): Science, Optics and Music in Medieval and Early Modern Thought. London (Hambledon Press) 1990. S. 441-451.

Pagnoni-Sturlese, Maria R.; Rehn, Rudolf; Sturlese, Loris (Hrsg.): Opera Omnia. Tomus IV. Schriften zur Naturwissenschaft. Briefe. Hamburg (Meiner) 1985. (= Corpus Philosophorum Teutonicorum Medii Aevi. II, 4)

Duhem, Pierre: To Save the Phenomena: An Essay on the Idea of Physical Theory from Plato to Galileo. Chicago, London (University of Chicago Press) 1969.

EASTwOOD, Bruce S.: Grosseteste's "Quantitative" Law of Refraction: A Chapter in the History of Non-Experimental Science. In: Journal of the History of Ideas, XXVIII. Jg. (1967), S. 403-414.

EAstwood, Bruce S.: Medieval Empiricism: The Case of Grosseteste's Optics. In: Speculum, XLIII. Jg. (1968), S. 306-321.

FICHANT, Michel; PÊCHEUX, Michel (Hrsg.): Überlegungen zur Wissenschaftsgeschichte. Frankfurt am Main (Suhrkamp) 1977.

FICHANT, Michel: Die Idee einer Wissenschaftsgeschichte. Aus: Fichant, Michel; Pêcheux, Michel (Hrsg.): Überlegungen zur Wissenschaftsgeschichte. Frankfurt am Main (Suhrkamp) 1977. S. 44-114.

Grant, Edward (Hrsg.): A Source Book in Medieval Science. Cambridge, Massachusetts (Harvard University Press) 1974.

GRANT, Edward: Das physikalische Weltbild des Mittelalters. München (Artemis) 1980.

Grant, Edward (Hrsg.): Studies in Medieval Science and Natural Philosophy. London (Variorum Reprints) 1981.

Grant, Edward: The Condemnation of 1277, God's Absolute Power, and Physical Thought in the Late Middle Ages. Aus: Grant, Edward (Hrsg.): Studies in Medieval Science and Natural Philosophy. London (Variorum Reprints) 1981. S. 211-244. 
Grant, Edward; Murdoch, John E. (Hrsg.): Mathematics and its applications to science and natural philosophy in the Middle Ages: Essays in honor of Marshall Clagett. Cambridge (Cambridge Univerity Press) 1987.

HACKING, Ian: Einführung in die Philosophie der Naturwissenschaften. Stuttgart (Reclam) 1996.

HARRÉ, Rom: Great Scientific Experiments: Twenty Experiments that changed our View of the World. Oxford, New York (Oxford University Press) 1981.

KOYRÉ, Alexandre: Die Ursprünge der modernen Wissenschaft: Ein neuer Deutungsversuch. In: Diogenes, 4. Jg. (1957), S. 421-448.

KOYRÉ, Alexandre: Von der geschlossenen Welt zum unendlichen Universum. Frankfurt am Main (Suhrkamp) 1980.

KuHN, Thomas S.: Die grundlegende Spannung: Tradition und Neuerung in der wissenschaftlichen Forschung. Aus: Kuhn, Thomas S. (Hrsg.): Die Entstehung des Neuen: Studien zur Struktur der Wissenschaftsgeschichte. Frankfurt am Main (Suhrkamp) 1992. S. 308-326.

KuHn, Thomas S.: Die historische Struktur wissenschaftlicher Entdeckungen. Aus: Kuhn, Thomas S. (Hrsg.): Die Entstehung des Neuen: Studien zur Struktur der Wissenschaftsgeschichte. Frankfurt am Main (Suhrkamp) 1992. S. 239-253.

KuHn, Thomas S.: Die Beziehung zwischen Wissenschaftsgeschichte und Wissenschaftstheorie. Aus: Kuhn, Thomas S. (Hrsg.): Die Entstehung des Neuen: Studien zur Struktur der Wissenschaftsgeschichte. Frankfurt am Main (Suhrkamp) 1992. S. 49-71.

Kunn, Thomas S.: Die Wissenschaftsgeschichte. Aus: Kuhn, Thomas S. (Hrsg.): Die Entstehung des Neuen: Studien zur Struktur der Wissenschaftsgeschichte. Frankfurt am Main (Suhrkamp) 1992. S. 169-193.

KuHn, Thomas S.: Die Beziehung zwischen Geschichte und Wissenschaftsgeschichte. Aus: Kuhn, Thomas S. (Hrsg.): Die Entstehung des Neuen: Studien zur Struktur der Wissenschaftsgeschichte. Frankfurt am Main (Suhrkamp) 1992. S. 194-236.

KuHn, Thomas S.: Neue Überlegungen zum Begriff des Paradigma. Aus: Kuhn, Thomas S. (Hrsg.): Die Entstehung des Neuen: Studien zur Struktur der Wissenschaftsgeschichte. Frankfurt am Main (Suhrkamp) 1992. S. 389-420.

KuHN, Thomas S.: Mathematische versus experimentelle Tradition in der Entwicklung der physikalischen Wissenschaften. Aus: Kuhn, Thomas S. (Hrsg.): Die Entstehung des Neuen: Studien zur Struktur der Wissenschaftsgeschichte. Frankfurt am Main (Suhrkamp) 1992. S. 84-124.

KuHN, Thomas S. (Hrsg.): Die Entstehung des Neuen: Studien zur Struktur der Wissenschaftsgeschichte. Frankfurt am Main (Suhrkamp) 1992.

KuHN, Thomas S.: Die Struktur wissenschaftlicher Revolutionen. Frankfurt am Main (Suhrkamp) 1996.

LindBerg, David C.: Roger Bacon's Theory of the Rainbow: Progress or Regress? Aus: Lindberg, David C. (Hrsg.): Studies in the History of Medieval Optics. London (Variorum Reprints) 1983. S. 235-248. 
LindBerg, David C.: Alhazen's Theory of Vision and its Reception in the West. Aus: Lindberg, David C. (Hrsg.): Studies in the History of Medieval Optics. London (Variorum Reprints) 1983. S. 321-341.

LindBerg, David C.: The Cause of Refraction in Medieval Optics. Aus: Lindberg, David C. (Hrsg.): Studies in the History of Medieval Optics. London (Variorum Reprints) 1983. S. 23-38.

LINDBERG, David: The Science of Optics. Aus: Lindberg, David C. (Hrsg.): Studies in the History of Medieval Optics. London (Variorum Reprints) 1983. S. 338-368.

LindBerg, David C. (Hrsg.): Studies in the History of Medieval Optics. London (Variorum Reprints) 1983.

LindBERG, David C.: Roger Bacon and the origins of perspectiva in the West. Aus: Grant, Edward; Murdoch, John E. (Hrsg.): Mathematics and its applications to science and natural philosophy in the Middle Ages: Essays in honor of Marshall Clagett. Cambridge (Cambridge Univerity Press) 1987. S. 249-268.

LindBerg, David C.: Auge und Licht im Mittelalter: Die Entwicklung der Optik von Alkindi bis Kepler. Frankfurt am Main (Suhrkamp) 1987.

LOSEE, John: A historical Introduction to the philosophy of science. Oxford (Oxford University Press) 1993.

Merton, Robert K.: Puritanismus und Wissenschaft. Aus: Merton, Robert K. (Hrsg.): Entwicklung und Wandel von Forschungsinteressen: Aufsätze zur Wissenschaftssoziologie. Frankfurt am Main (Suhrkamp) 1985. S. 59-85.

Merton, Robert K. (Hrsg.): Entwicklung und Wandel von Forschungsinteressen: Aufsätze zur Wissenschaftssoziologie. Frankfurt am Main (Suhrkamp) 1985.

Pichот, André: Die Geburt der Wissenschaft: Von den Babyloniern zu den frühen Griechen. Darmstadt (WBG) 1995.

RossI, Paolo: Die Geburt der modernen Wissenschaft in Europa. München (Beck) 1997. (= Europa Bauen)

ScotT, J. F.: The Scientific Work of René Descartes (1596-1650). London (Taylor \& Francis) 1976.

SMIth, A. Mark: Getting the Big Picture in Perspectivist Optics. In: Isis, 72. Jg. (1981), S. 568-589.

STURLESE, Loris: Dokumente und Forschungen zu Leben und Werk Dietrichs von Freiberg. Hamburg (Meiner) 1984. (=Corpus Philosophorum Teutonicorum Medii Aevi. Beiheft 3)

StURLeSe, Loris: Einleitung. Aus: Pagnoni-Sturlese, Maria R.; Rehn, Rudolf; Sturlese, Loris; u. a. (Hrsg.): Opera Omnia. Tomus IV. Schriften zur Naturwissenschaft. Briefe. Hamburg (Meiner) 1985. (= Corpus Philosophorum Teutonicorum Medii Aevi. II, 4) S. XIII-XLV.

Unguru, Sabetai: Mathematics and Experiment in Witelo's Perspectiva. Aus: Grant, Edward; Murdoch, John E. (Hrsg.): Mathematics and its applications to science and natural philosophy in the Middle Ages: Essays in honor of Marshall Clagett. Cambridge (Cambridge Univerity Press) 1987. S. 269-297. 
Unguru, Sabetai (Hrsg.): Physics, Cosmology and Astronomy 1300-1700: Tension and Accomodation. Dordrecht, Boston, London (Kluwer) 1991. (= Boston Studies in the Philosophy of Science. 126)

Unguru, Sabetai: Experiment in Medieval Optics. Aus: Unguru, Sabetai (Hrsg.): Physics, Cosmology and Astronomy 1300-1700: Tension and Accomodation. Dordrecht, Boston, London (Kluwer) 1991. (= Boston Studies in the Philosophy of Science. 126) S. 163-181.

Wallace, William A.: The Scientific Methodology of Theodoric of Freiberg: A Case Study of the Relationship between Science and Philosophy. Fribourg (University Press) 1959. (= Studia Friburgensia. NF 26) 